Review

\title{
Reviews on the Japanese Patent Applications Regarding Nickel/Metal Hydride Batteries
}

\author{
Taihei Ouchi ${ }^{1}$, Kwo-Hsiung Young ${ }^{1,2, *}$ and Dhanashree Moghe ${ }^{3}$ \\ 1 BASF/Battery Materials—Ovonic, 2983 Waterview Drive, Rochester Hills, MI 48309, USA; \\ taihei.ouchi@basf.com \\ 2 Department of Chemical Engineering and Materials Science, Wayne State University, Detroit, MI 48202, USA \\ 3 Department of Chemical Engineering and Materials Science, Michigan State University, East Lansing, \\ MI 48824, USA; damoghe@gmail.com \\ * Correspondence: kwo.young@basf.com; Tel.: +1-248-293-7000
}

Academic Editor: Andreas Jossen

Received: 3 May 2016; Accepted: 20 June 2016; Published: 30 June 2016

\begin{abstract}
The Japanese Patent Applications filed on the topic of nickel/metal hydride (Ni/MH) batteries have been reviewed. Patent applications filed by the top nine battery manufacturers (Matsushita, Sanyo, Hitachi Maxell, Yuasa, Toshiba, FDK, Furukawa, Japan Storage, and Shin-kobe), five component suppliers (Tanaka, Mitsui, Santoku, Japan Metals \& Chemicals Co. (JMC), and Shin-Etsu), and three research institutes (Industrial Research Institute (ISI), Agency of Industrial Science and Technology (AIST), and Toyota R \& D) were chosen as the main subjects for this review, based on their production volume and contribution to the field. By reviewing these patent applications, we can have a clear picture of the technology development in the Japanese battery industry. These patent applications also provide insights, know-how, and future directions for engineers and scientists working in the rechargeable battery field.
\end{abstract}

Keywords: metal hydride (MH); nickel/metal hydride (Ni/MH) battery; nickel hydroxide; electrode fabrication; Japan patent application

\section{Introduction}

Since the debut of commercial nickel/metal hydride (Ni/MH) batteries in the late 1980's, over one thousand Japanese Patents have been granted. Many Japanese companies have worked very diligently in the past and some are still very active in the new product and market development. As a result, the Ni/MH battery market aims to maintain a smooth growth into the future (Figure 1), especially in the hybrid electric vehicle (HEV) and stationary markets. It was predicted by Yano Research Institute (Tokyo, Japan) that the use of Ni/MH in HEVs will increase four-fold from 2014 to 2020 [1] (Figure 2). Although some key inventions conceived in Japan have also been filed to the U.S. Patent and Trademark Office (for a review, see [2]), many of them have not. In order to facilitate the research and development world outside Japan, a review of the Japanese Patent Applications on the subject of $\mathrm{Ni} / \mathrm{MH}$ batteries is presented here. The summary of the Japanese Patent Application in English is available online by inputting the H-number (before 2000) or Year-number (since 2000) in the "A: publication of patent application" row [3]. Machine translations of the claims and specification into English are available by selecting "Detail" in the corresponding webpage. 


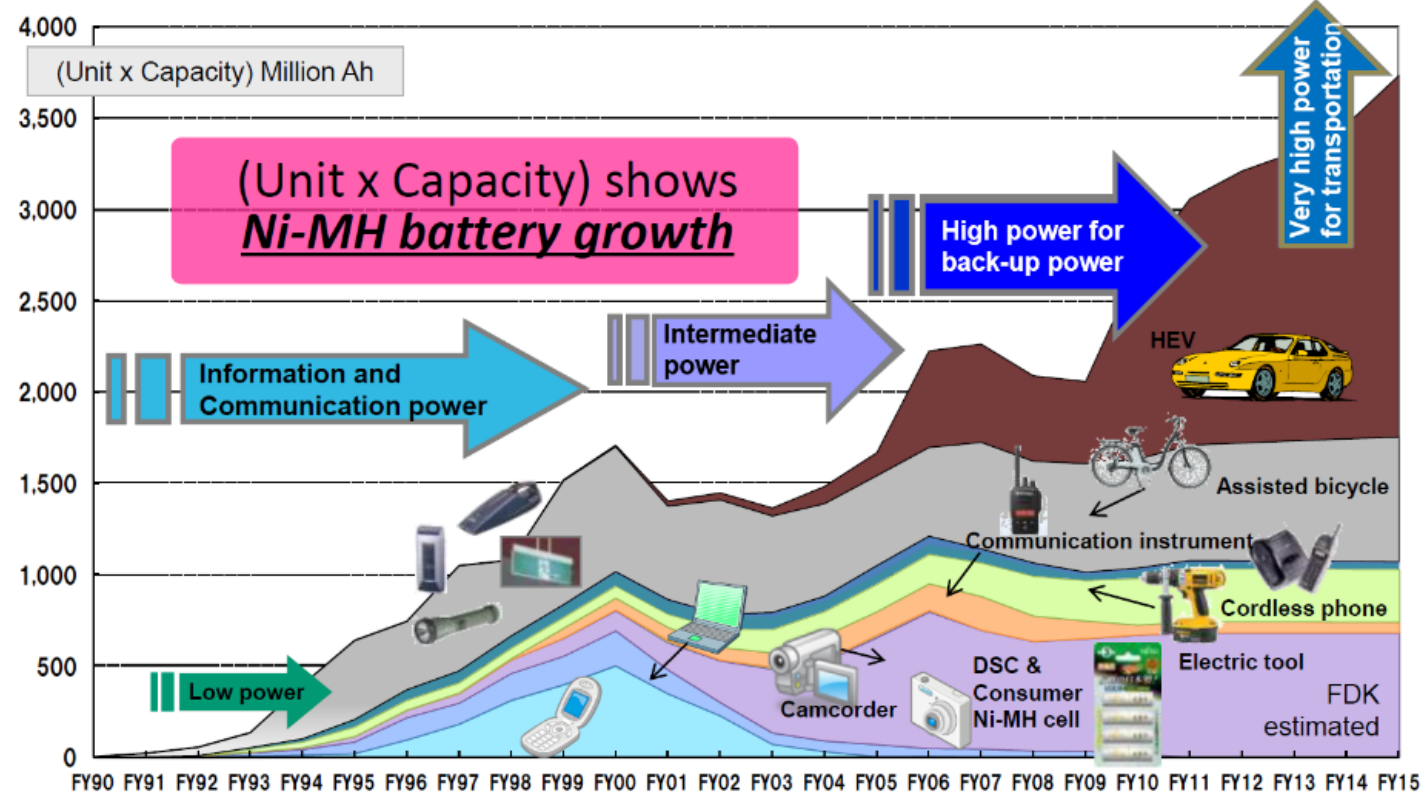

Figure 1. The nickel/metal hydride $(\mathrm{Ni} / \mathrm{MH})$ market prediction by FDK. While the demand for Ni/MH in hybrid electric vehicle (HEV) is increasing, uses in other areas remain stable. Courtesy of FDK Corp. DSC stands for digital still camera. The power requirement for $\mathrm{Ni} / \mathrm{MH}$ batteries started slowly and grows strongly into transportation applications (HEV, start-stop vehicle, and trains) as indicated by the arrows.

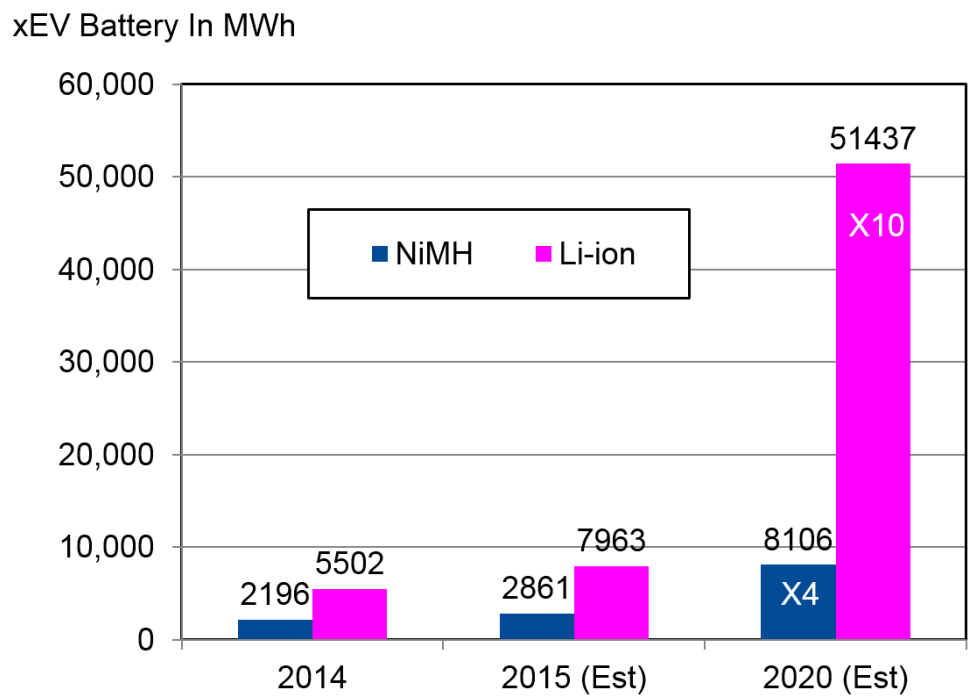

Figure 2. Prediction of $\mathrm{Ni} / \mathrm{MH}$ and Li-ion batteries in the $\mathrm{xEV}$, including electric vehicles, plug-in $\mathrm{HEV}$, and HEV. Data from Yano's Report [1].

\section{Results}

In this review, we have separated patent applications filed in Japan from battery manufacturers, component supplying companies, and independent research institutes. The reason for selecting the patent application, instead of the patent itself, is to increase the scope of coverage. For each company, we picked the most influential patent applications, based on the length of effective days, and summarized their contents here. The background of these companies is briefly introduced in Table 1 . 
Table 1. Brief introduction to the Japanese companies included in this review. The number of consolidated employees includes those in the parent company who are not directly involved in the battery business. JMC: Japan Metals \& Chemicals; MH: metal hydride; and AIST: Agency of Industrial Science and Technology.

\begin{tabular}{|c|c|c|c|c|c|}
\hline Company Name & Established Date & Main Business & Trademark & Employee & Remark \\
\hline $\begin{array}{l}\text { Matsushita } \\
\text { (Panasonic) }\end{array}$ & 1918 & Home appliances and electronics & Panasonic & Consolidated: 254,084 & - \\
\hline SANYO Electric & 1947 & Home appliances and electronics & & $\begin{array}{l}\text { Merge into Panasonic } \\
\text { in December } 2009\end{array}$ & $\mathrm{Ni} / \mathrm{MH}$ division was sold to FDK in January 2010 \\
\hline Hitachi Maxell & 1960 & $\begin{array}{l}\text { Energy, industrial materials and electronic } \\
\text { appliance/consumer products }\end{array}$ & ma) & Consolidated: 4053 & - \\
\hline Yuasa & 1918 & Storage batteries and other products & ASA & $\begin{array}{l}\text { Consolidated: } 14,506 \\
\text { as GS Yuasa }\end{array}$ & $\begin{array}{l}\text { Managed integration through the establishment of } \\
\text { a holding company (GS Yuasa Corporation) in } \\
\text { April } 2004 .\end{array}$ \\
\hline Toshiba Battery & 1954 & Storage batteries and other products & TOSHIBA & $\begin{array}{c}\text { Merge into Toshiba } \\
\text { Home Appliances, } \\
\text { and dissolved in } 2009 \\
\end{array}$ & Ni/MH div. was sold to SANYO in 2000 \\
\hline FDK & 1950 & $\begin{array}{l}\text { Various kinds of batteries, rechargeable } \\
\text { batteries, battery devices, electronic } \\
\text { components, and devices }\end{array}$ & & $\begin{array}{l}4917 \text { consolidated } \\
\text { basis }\end{array}$ & $\begin{array}{l}\text { Acquired Sanyo Energy Twicell Co., Ltd. and } \\
\text { Sanyo Energy Tottori Co., Ltd. in } 2000\end{array}$ \\
\hline $\begin{array}{l}\text { Furukawa } \\
\text { Battery }\end{array}$ & 1950 & $\begin{array}{c}\text { Various kinds of batteries, rechargeable } \\
\text { batteries, battery devices, electronic } \\
\text { components, and devices }\end{array}$ & & Consolidated: 1999 & - \\
\hline $\begin{array}{l}\text { Japan Storage } \\
\text { Battery }\end{array}$ & 1917 & Storage batteries and other products & 5 & $\begin{array}{l}\text { Consolidated: } 14,506 \\
\text { as GS Yuasa }\end{array}$ & $\begin{array}{c}\text { Managed integration through the establishment of } \\
\text { a holding company (GS Yuasa Corporation) in } \\
\text { April } 2004 .\end{array}$ \\
\hline $\begin{array}{l}\text { Shin-Kobe } \\
\text { Electric } \\
\text { Machinery }\end{array}$ & 1969 (consolidation) & $\begin{array}{c}\text { Various kinds of batteries, rechargeable } \\
\text { batteries, battery devices, electronic } \\
\text { components and devices, and polymer } \\
\text { science materials }\end{array}$ & m & $\begin{array}{l}\text { Merge into Hitachi } \\
\text { Chemical, and } \\
\text { dissolved in Jan. } 2016\end{array}$ & Subsidiary of Hitachi Chemical in March 2012 \\
\hline Tanaka Chemical & 1957 & $\begin{array}{l}\text { Positive electrode materials for } \\
\text { rechargeable batteries, catalyst materials, } \\
\text { inorganic chemical products }\end{array}$ & Tanaka Chemical Corporation & 180 & - \\
\hline
\end{tabular}


Table 1. Cont

\begin{tabular}{|c|c|c|c|c|c|}
\hline Company Name & Established Date & Main Business & Trademark & Employee & Remark \\
\hline Mitsui Kinzoku & 1950 & $\begin{array}{l}\text { Manufacturing and sales of functional } \\
\text { materials, electronic materials, and } \\
\text { automotive parts/components, etc. }\end{array}$ & $\begin{array}{l}\text { MIISUI } \\
\text { KINZOKU }\end{array}$ & Consolidated: 10,804 & - \\
\hline Santoku & 1949 & Rare earths & 33 三德 & 229 & - \\
\hline JMC & 1917 & $\begin{array}{l}\text { Ferroalloy, MH and non-ferrous metals, } \\
\text { ferrite and ceramic products, geothermal } \\
\text { energy consulting service, and electric } \\
\text { power generation }\end{array}$ & & Consolidated: 921 & - \\
\hline $\begin{array}{l}\text { Shin-Etsu } \\
\text { Chemical }\end{array}$ & 1926 & $\begin{array}{l}\text { PVC/Chlor-Alkali, silicones, specialty } \\
\text { chemicals, electronics \& functional } \\
\text { material, and diversified }\end{array}$ & Shín'LSI & Consolidated: 18,276 & - \\
\hline AIST & 1952 & $\begin{array}{l}\text { AIST takes initiative as a leading research } \\
\text { institute for innovation while placing its } \\
\text { major emphasis on research that offers } \\
\text { practical benefits to the world }\end{array}$ & $C$ & 2929 & $\begin{array}{l}\text { Reformed in } 2001 \text { (National Institute of Advanced } \\
\text { Industrial Science and Technology) }\end{array}$ \\
\hline
\end{tabular}




\subsection{Battery Manufacturers}

Nine $\mathrm{Ni} / \mathrm{MH}$ manufacturers were chosen for this section. Examples of their consumer products are shown in Figure 3.

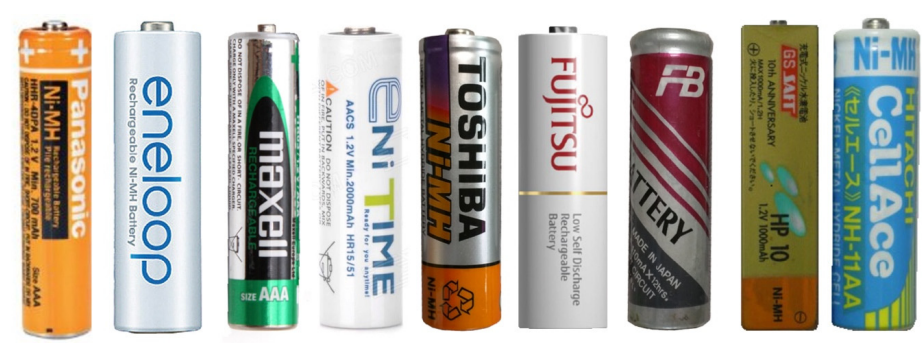

Figure 3. Ni/MH consumer products from major Japanese manufacturers-from left to right: Matsushita (Panasonic), Sanyo, Maxell, Yuasa, Toshiba, FDK, Furukawa, GS-Saft, and Shin-kobe. All are cylindrical, except the stick-type (gum) made by GS-Saft for portable digital assistant and cell phone use.

\subsubsection{Matsushita}

Matsushita Electric Industrial (Kadoma, Osaka, Japan) was one of the first companies to sell commercial Ni/MH batteries. In 1996, Matsushita and Toyota formed a joint venture, Panasonic EV Energy Co. (PEVE, now Primearth EV Co., Okasaki, Shizuoka, Japan), to manufacture Ni/MH batteries for propulsion application. In 2008, its name was changed to "Panasonic Corporation" and this company continued to manufacture Ni/MH consumer batteries in Wuxi, Jiangsu, China. The Ni/MH batteries, under the tradename Evolta, reached a cycle life of 1600 by sharing the positive electrode developed for their primary cell with the same trade name [4], which was the world record of the longest life for Ni/MH batteries in 2008. In 2009, Panasonic acquired Sanyo and sold its major stocks of PEVE to Toyota. The consumer battery manufacturing section was sold to FDK and the cylindrical cell manufacturing facility in Shonan, Kanagawa, Japan was sold to the Chinese Corun Company (Changsha, Hunan, China). Today, Panasonic continues to operate Sanyo's facility in Awajishima, making high-power cylindrical cell for start-stop vehicles. In the melt-and-cast preparation of $\mathrm{MH}$ alloys, Matsushita filed two patent applications: one on water atomization (Figure 4, [5]) and the other one on a double-roller casting mechanism (Figure 5, [6]).

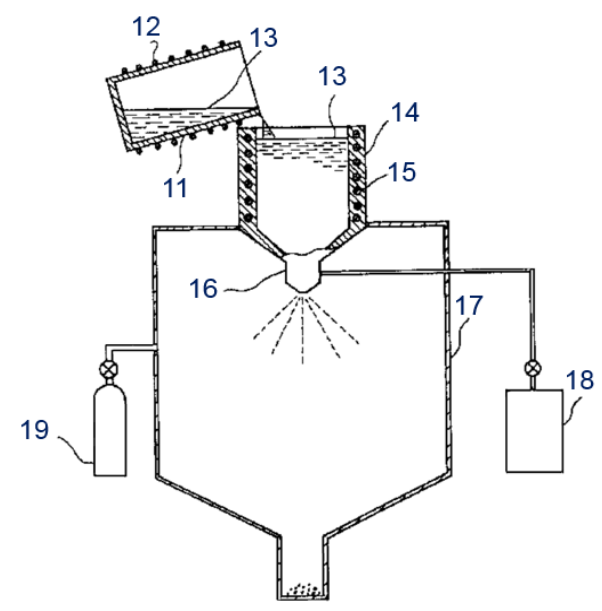

Figure 4. Schematic diagram of a water atomization system patented by Matsushita. Numbered parts are 11: induction melting furnace; 12: coil; 13: MH alloy; 14: holding furnace; 15: coil; 16: injection nozzle; 17: collection tank; 18: high pressure water pump; and 19: nitrogen cylinder. Reproduced from [5]. 


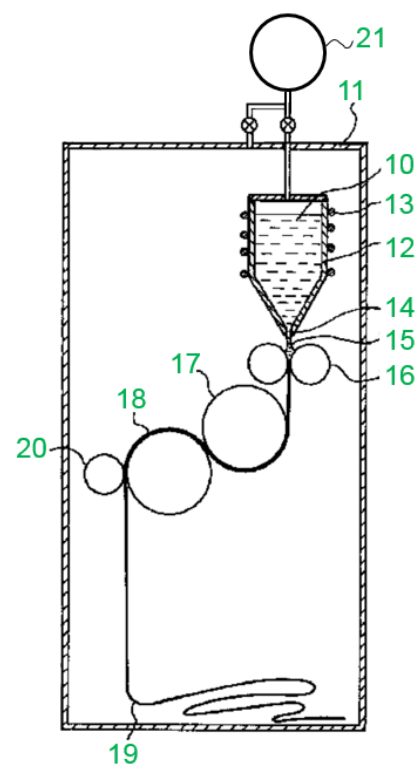

Figure 5. Schematic diagram of a double-roller casting system patented by Matsushita. Numbered parts are 10: $\mathrm{MH}$ alloy; 11: vacuum chamber; 12: induction furnace; 13: coil; 14: nozzle; 15: melt; 16: high temperature double-roller; 17, 18: water-cooled rollers; 19: alloy film; 20: pressing roller; and 21: Ar gas cylinder. Reproduced from [6].

A few patent applications filed between 1996 and 1998 were selected to demonstrate the coverage Matsushita acquired in the area of $\mathrm{Ni} / \mathrm{MH}$ batteries: an $\mathrm{AB}_{5}$ metal hydride $(\mathrm{MH})$ alloy containing a small amount of $\mathrm{Fe}, \mathrm{Cr}$, or $\mathrm{Cu}$ to lower the raw material cost [7], a $\mathrm{Zr}$-based $\mathrm{AB}_{2} \mathrm{MH}$ alloy with improved cycle life [8], a negative electrode of high surface area with a carbon content between $350 \mathrm{ppm}$ and $1000 \mathrm{ppm}$ [9], a positive electrode with spherical particles with an average diameter of less than $1.7 \mu \mathrm{m}$ and the percentage of the particles smaller than $1.0 \mu \mathrm{m}$ of below $20 \%$ [10], the effect of the addition of compounds from $\mathrm{Y}, \mathrm{Er}$, and $\mathrm{Yb}$ in the positive electrode to improve the high temperature performance [11], addition of ions from rare earth elements in the electrolyte to suppress the oxidation and capacity degradation of the negative electrode [12], $\mathrm{Co}(\mathrm{OH})_{2}$ coating on the $\mathrm{Ni}(\mathrm{OH})_{2}$ spherical particle surface to increase the cycle stability by increasing the electrolyte holding power [13], a design of negative-to-positive ratio from 1.5 to 2.0 for the uninterrupted power supplier application [14], and a surface treatment method to improve the uniformity in capacity degradation during cycling (Figure 6, from [15]) and its application in high-rate batteries [16].

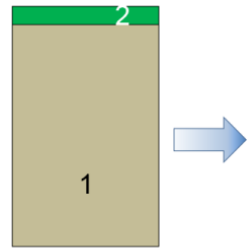

(a)

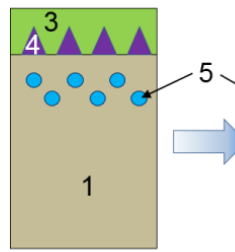

(b)

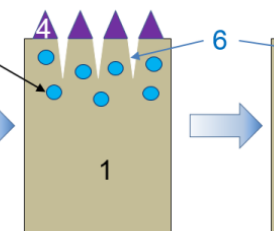

(c)

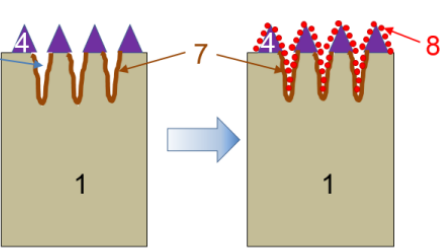

(d)

(e)

Figure 6. A schematic diagram of a surface preparation method for a negative electrode to pre-age the $\mathrm{MH}$ alloy in order to improve the uniformity in cycle degradation in the cell. From left to right, showing the surface microstructure (a) after a wet-grinding process; (b) after an alkaline treatment; (c) after an acid treatment; (d) after a de-hydrogenation process; and (e) after the final hydroxide ion modification. In the diagram, the components indicated by numbers are 1: bulk ingot; 2: hydroxide and incomplete oxide layer; 3 : hydroxide from the rare earth element layer; 4 : metallic $\mathrm{Ni} ; 5$ : hydrogen atoms; 6: pore; 7: Ni-rich layer; and 8: hydroxide ions. This surface treatment has become the standard procedure for $\mathrm{Ni} / \mathrm{MH}$ batteries used in the propulsion industry. Reproduced from [15]. 


\subsubsection{Sanyo}

Sanyo Electric Co. (Osaka, Japan) was the other company selling the first-generation commercial $\mathrm{Ni} / \mathrm{MH}$ batteries [17]. It began manufacturing $\mathrm{Ni} / \mathrm{MH}$ in 1990. In 2000, Sanyo purchased Toshiba's $\mathrm{Ni} / \mathrm{MH}$ manufacturing facility (Takasaki, Gumma, Japan) and became the largest producer of Ni/MH batteries in the world. In 2005, Sanyo introduced a low self-discharge Ni/MH battery, an eneloop, with less than $15 \%$ capacity loss during the first year of storage [18]. The battery is based on the $\mathrm{A}_{2} \mathrm{~B}_{7}$ superlattice Mg and rare earth elements containing MH alloys [19,20]. In 2009, Sanyo was acquired by Panasonic. In 2014, its Ni/MH manufacturing facility in Suzhou, Jiangsu, China was closed and the production line was moved back to Japan, where it continued to produce $\mathrm{Ni} / \mathrm{MH}$ batteries under the operation of FDK.

The representative patent applications filed by Sanyo include the following concepts: addition of fluoro-resin powder on the negative electrode surface to increase the gas recombination rate during overcharge [21], addition of polytetrafluoroethylene (PTFE) to the negative electrode for increasing its mechanical strength [22], a coating of the co-precipitated hydroxide from $\mathrm{Zn}, \mathrm{Cd}, \mathrm{Mg}$, or $\mathrm{Ca}$ on the $\mathrm{Ni}(\mathrm{OH})_{2}$ surface to prevent capacity loss due to over-discharge [23], a melt-spin fabrication method for preparing $\mathrm{MH}$ alloy with improved high-rate dischargeability (HRD) at a low temperature [24], a requirement in the uniformity of $\mathrm{MH}$ alloy particle size for better cycle life [25], addition of 0.5-10 ppm $\mathrm{Y}$ into electrolyte [26], a $\beta$-CoOOH coating [27] to improve the utilization of positive electrode active material, addition of $\mathrm{Mn}$ to prevent leakage of the electrolyte [28], a partially reduced metal between the $\mathrm{MH}$ alloy particles to improve the conductivity of the negative electrode [29], a special substrate made of metallic form with a hollow structured skeleton to prevent the breakage of substrate during winding [30], and a Li-containing Co coating to the $\mathrm{Ni}(\mathrm{OH})_{2}$ spherical particles to improve the utilization of the positive electrode active material [31]. After merging into Panasonic, most of the Sanyo's patents belong to the new owner, except the last two, which were acquired by FDK.

\subsubsection{Hitachi Maxell}

Hitachi Maxell Ltd. (Tokyo, Japan) is a consumer electronics manufacturer in Japan. In the early days, Hitachi Maxell teamed with Ovonic Battery Company (Troy, MI, USA) and manufactured $\mathrm{Ni} / \mathrm{MH}$ batteries based on the $\mathrm{AB}_{2} \mathrm{MH}$ alloys. In contrast to the previous two companies, Maxell's patent applications are more related to the fabrication at the cell level, instead of raw materials or electrodes. Some examples are: addition of a PTFE layer on the surface of MH alloy to increase the conductivity and mechanical strength of the negative electrode [32], a design of a safety-vent to prevent rupture of the battery [33], a disordered nickel hydroxide co-precipitated with 1.5-2.8 $\mathrm{wt} \%$ $\mathrm{Zn}$ to increase the capacity [34], addition of corrosion preventives in the electrolyte, such as $\mathrm{K}_{2} \mathrm{SiO}_{3}$, $\mathrm{K}_{4} \mathrm{Si}_{3} \mathrm{O}_{8}, \mathrm{~K}_{4} \mathrm{SiO}_{4}, \mathrm{~K}_{6} \mathrm{SiO}_{6}, \mathrm{~K}_{3} \mathrm{PO}_{4}, \mathrm{~K}_{4} \mathrm{PO}_{7}, \mathrm{~K}_{2} \mathrm{CrO}_{4}$ [35], Mo, W, and $\mathrm{Cr}$ ions [36] to improve cycle stability, a requirement in the uniformity of spherical particle size in the positive electrode [37], a method of assembling two different chemistries in one hybrid container [38], an electrolyte filling amount of $1.4 \mathrm{cc} \cdot(\mathrm{Ah})^{-1}$ [39], a $\mathrm{Zn}-\mathrm{Co}$ layer on the $\mathrm{Ni}(\mathrm{OH})_{2}$ spherical particle to increase the utilization and lower the raw material cost [40], and an Ni-rich secondary phase in the $\mathrm{AB}_{5} \mathrm{MH}$ alloy to improve low-temperature HRD [41,42].

\subsubsection{Yuasa}

Yuasa Battery Co. (Takatsuki, Osaka, Japan) was the first automobile battery company in Japan (1920). Yuasa was also the first company to develop spherical $\mathrm{Ni}(\mathrm{OH})_{2}$ for the high-density positive electrode used in Ni/MH batteries. Oshitani and Yufu [43] disclosed a $\beta-\mathrm{Co}(\mathrm{OH})_{2}$-coated $\mathrm{Ni}(\mathrm{OH})_{2}$ in his patent application filed in 1988, which is still used in today's Ni/MH batteries (Figure 7). In 1997, Yuasa formed a joint venture with Taiwanese Delta Electronics (Taipei, Taiwan) in Tianjin, China to manufacture $\mathrm{Ni} / \mathrm{MH}$ batteries, which was productive until a recent shutdown in 2015 due to an accidental explosion. In 2004, Yuasa merged with Japan Storage Battery Co. and formed GS Yuasa Co. The company has a product similar to FDK's eneloop—-the eNiTIME. It comes pre-charged and can be used right out of the box [44]. 


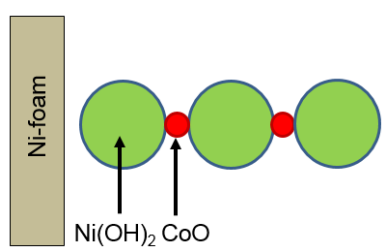

(a)

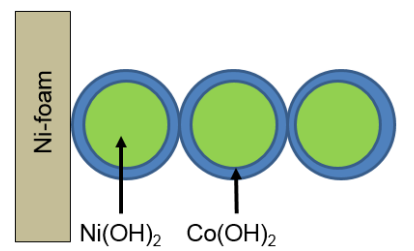

(b)

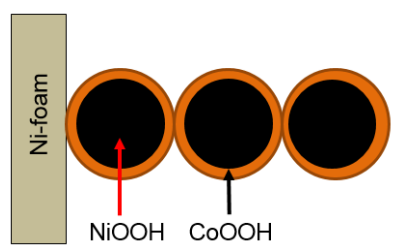

(c)

Figure 7. Schematic diagrams showing the formation of a conductive network in the positive electrode: (a) as prepared with $\mathrm{CoO}$ additives; (b) after the dissolution and re-deposition of $\mathrm{Co}(\mathrm{OH})_{2}$; and (c) after the first charge into $\mathrm{CoOOH}$. Reproduced from [43].

Since 1980, Yuasa has filed 327 patent applications on alkaline batteries [45] that cover both the positive and negative electrodes. We have picked the following as the most representative patents with an emphasis on: a bi-polar design electrode design [46], an ex-situ oxidation applied to the Co-conductive network of the positive electrode [47], a dual polyolefin/vinyl monomer composite used as a separator to reduce the self-discharge [48], a formation algorithm to increase the protection against overcharge and over-discharge [49], addition of $\mathrm{Y}$ and $\mathrm{Yb}$ compounds in the positive electrode to reduce the corrosion in the negative electrode [50], addition of a sulfonic group to the benzene nucleus forming a separator material with a lower self-discharge [51], a positive electrode with Co metal and/or Co oxide and at least one rare earth compound, alkaline earth metal compound and zinc oxide [52], an negative electrode additive made from Ce metal or a complex of Ce metal and another metal with a BET surface area $>50 \mathrm{~m}^{2} \cdot \mathrm{g}^{-1}$ [53] or fine Ni powder $(<2 \mu \mathrm{m})$ [54] to improve the performance of the battery, and $\mathrm{MH}$ alloy containing a rare earth element with an atomic number $>62$ $(\mathrm{Eu}, \mathrm{Gd}, \mathrm{Tb}, \mathrm{Dy}, \mathrm{Ho}, \mathrm{Er}, \mathrm{Tm}, \mathrm{Yb}$, and Lu) [55].

\subsubsection{Toshiba}

Toshiba Corp. (Tokyo, Japan) is a heavily diversified conglomerate corporation in electronics, nuclear, and electrical appliances. It was one of the earliest $\mathrm{Ni} / \mathrm{MH}$ manufacturers. Toshiba, together with Duracell (Bethel, CT, USA) and Varta Battery (Elleangen, Germany, now bankrupted), formed a joint venture, 3C Alliance LLP, in 1996 and achieved annual sales of 100 million cells. Toshiba sold its $\mathrm{Ni} / \mathrm{MH}$ operation to Sanyo in 2000. Examples of patent applications from Toshiba include: a battery module with space filled with resin to improve the temperature uniformity during charge [56], a negative electrode with polymer binder containing PTEE of an average molecular weight of 200,000-1,000,000 [57], an Mg-containing ( $>10$ at\%) MH alloy with some unique X-ray diffraction (XRD) intensity ratio characteristics [58], Mg-based $\mathrm{AB}_{2}$ and $\mathrm{A}_{2} \mathrm{~B} \mathrm{MH}$ alloys as negative electrode active materials [59], a high energy density cell with Mn content between $0.6 \mathrm{wt} \%$ and $2.6 \mathrm{wt} \%$ [60], a method to increase the loading of a negative electrode [61], a method to suppress the self-discharge in the early stage of cycle life [62], improvement in the low-temperature performance [63], Mg-containing $\mathrm{MH}$ alloys with layered crystal structure [64], and an $\mathrm{MH}$ alloy containing $\mathrm{Mg}$, a rare earth element, and alkaline metals [65]. The last six patents now belong to Yuasa.

In 2000, right before transferring the $\mathrm{Ni} / \mathrm{MH}$ business to Sanyo, scientists at Toshiba filed a series of patent applications regarding newly discovered superlattice alloys, trying to summarize the laboratory findings up to that day, without significant conclusions. These patent applications may be considered immature compared to today's technology, which has been fine-tuned by Sanyo and FDK, but they are good examples of how a large battery company performed research, starting from ground level. They include patent applications about engineering the $\mathrm{Mg}$ content within an $\mathrm{MH}$ alloy particle [66], improvement in low-temperature performance by increasing the surface metallic $\mathrm{Ni}$ content [67], improvement in capacity and cycle life by controlling the lattice parameter $c$ in the crystal structure [68], a rapid cooling method to prevent loss of $\mathrm{Mg}$ [69], and an optimized composition range for capacity and cycle life (Figure 8, data from [70]). 


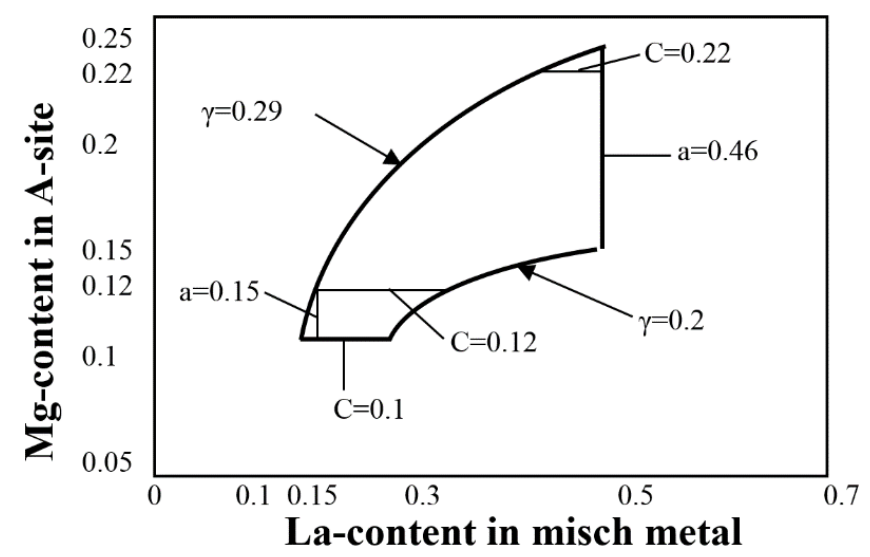

Figure 8. A composition map of superlattice $\mathrm{MH}$ alloys showing range optimized by capacity and cycle life [70]. The $x$-axis is the La content in the misch metal ( $\mathrm{La}, \mathrm{Ce}, \mathrm{Pr}$, and $\mathrm{Nd}$ ) represented by "a" in the chart. The $y$-axis is the $\mathrm{Mg}$ content in the A-site atoms $\left(\mathrm{Mg}, \mathrm{La}, \mathrm{Ce}, \mathrm{Pr}\right.$, and $\mathrm{Nd}$ ) represented by " $\mathrm{C}^{\text {" }}$ in the chart. In the chart, $\gamma$ is a quantity defined by $C+0.025 / a$.

\subsubsection{FDK}

FDK Corp. (original name: Fuji Denki Kagaku) was originally an electronic company making primary Li batteries and other electronic components. In 2010, it acquired the Twicell Division (Ni/MH battery branch making eneloop batteries) of Sanyo and continues to operate as the world's largest producer of $\mathrm{Ni} / \mathrm{MH}$ batteries in Takasaki, Japan. One example, showing the continuity of research from one company to the next company, is shown in Figures 9 and 10. Since its debut, the superlattice alloy was targeted to replace the $\mathrm{AB}_{5} \mathrm{MH}$ alloy with the goal of increasing the capacity. However, a corrosion problem came with the $\mathrm{Mg}$ component and led to a short cycle life. Therefore, a ten-year campaign to find the most suitable oxidation inhibitor for superlattice alloys started in Toshiba, then Sanyo, finally accomplished by FDK.

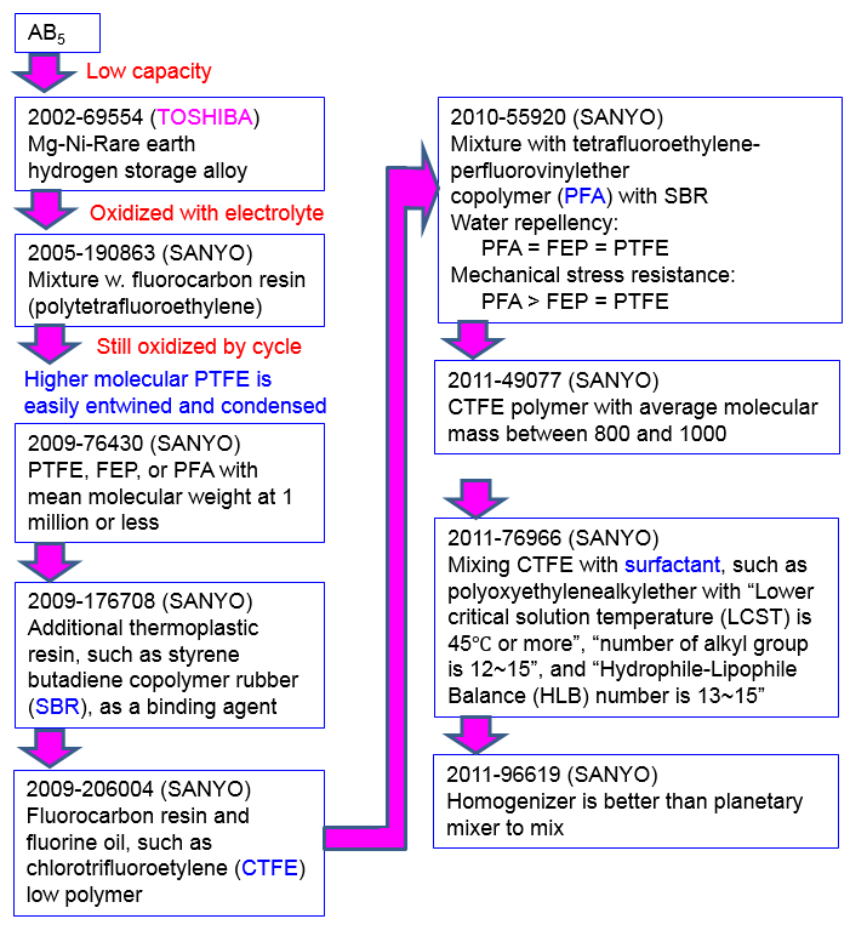

Figure 9. Early Japanese Patent Applications regarding the use of newly developed superlattice MH alloys. 


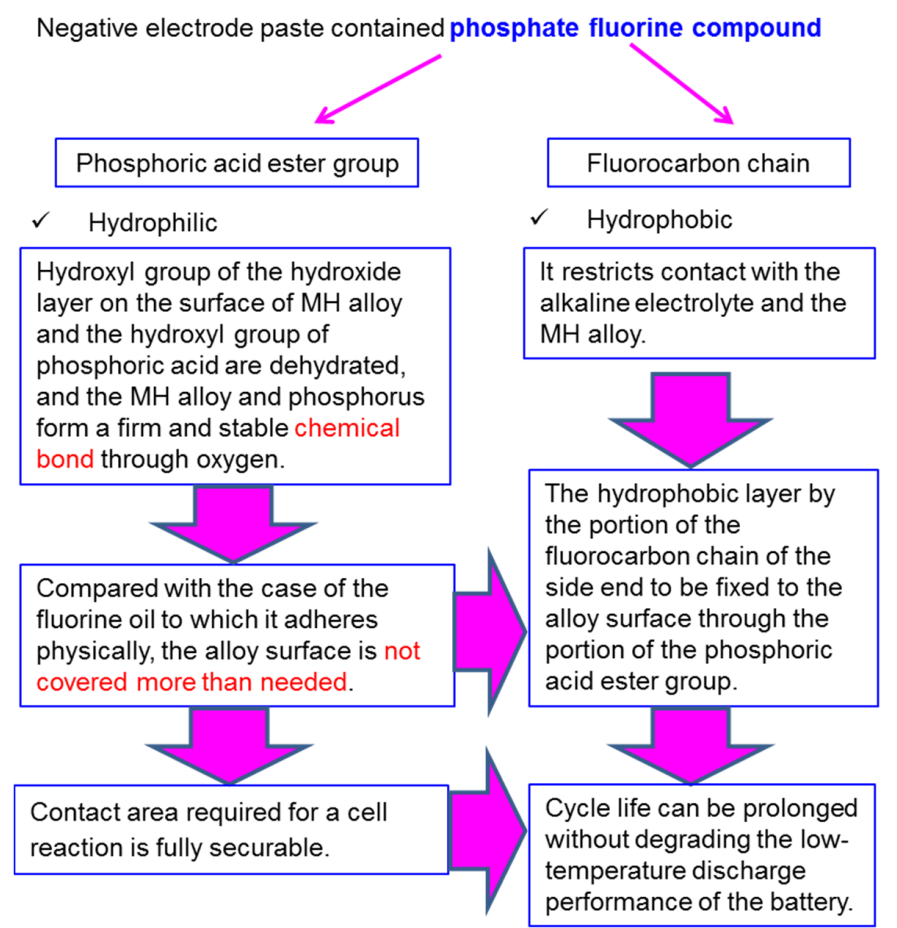

Figure 10. In a continuation of previous efforts (Figure 9), FDK filed a patent application to finalize the design of additives in negative electrode paste to extend the cycle life of cells, using superlattice alloys to $5000+[71]$.

FDK, being the only remaining domestic consumer $\mathrm{Ni} / \mathrm{MH}$ battery producer, filed patent applications that were centered on: an LHLHHH type of stacking sequence along the $c$-axis for a superlattice alloy where $\mathrm{L}$ and $\mathrm{H}$ are $\mathrm{A}_{2} \mathrm{~B}_{4}$ and $\mathrm{AB}_{5}$ layers, respectively [72], larger $\mathrm{MH}$ alloy particles used in the outside rim of a cylindrical cell to improve its cycle stability [73], a positive electrode using nickel hydroxide from co-precipitation of $\mathrm{Mg}$ to reduce the voltage lowering during storage [74], a Ca-containing [75] and an Sm-rich [76], Zr-containing [77] superlattice alloy to increase both the capacity and the cycle life, an electrolyte recipe composed of $\mathrm{KOH}, \mathrm{NaOH}$, and $\mathrm{LiOH}$ to optimize cycle life and low-temperature characteristics [78], an $\mathrm{NaOH}$-dominant electrolyte for improving both cycle life and self-discharge performances [79], a $\mathrm{TeO}_{2}$-containing electrolyte to improve low-temperature discharge characteristics [80], the additives in the negative electrode containing $\mathrm{CaF}_{2}, \mathrm{CaS}$, and/or $\mathrm{CaCl}_{2}$ [81], and $\mathrm{AlF}_{3}$ [82] to improve alloy performance, application of $\mathrm{MH}$ alloy particle of different sizes onto each side of the electrode to prevent short-circuit [83], an NaF-containing electrolyte to improve the self-discharge characteristics of the cell [84], a low-La ( $<25 \%$ in A-site element) superlattice alloy to have improved voltage standing during long-period storage [85], and a multi-layer construction for a negative electrode with different binder contents to improve the capacity degradation and short-circuit of the cell [86].

\subsubsection{Furukawa}

Furukawa Battery Co. (Yokohama, Kanagawa, Japan) is a company that manufactures mainly lead-acid and alkaline batteries. It constructed a Ni/MH plant in Iwaki, Fukushima, Japan in 1993. In 1997, it was one of seven Ni/MH battery manufacturers in Japan (the others were Matsushita, Sanyo, Toshiba, Yuasa, GS-Saft, and Hitachi-Maxell [87]). Patent applications filed by Furukawa include: a $5 \%-15 \%$ porosity in the negative electrode assembly to suppress the pressure build-up during cycling [88], a sponge nickel sheet as the positive electrode substrate and a punched nickel sheet ( $30 \%-44 \%$ open space) as the negative electrode substrate to increase the energy density of the cell [89], a formation process including both electrical activation and thermal aging processes to ensure 
high HRD [90], a heat treatment $\left(100-250^{\circ} \mathrm{C}\right)$ of the $\mathrm{MH}$ alloy powder before electrode assembly to suppress the pressure increase during overcharge [91], a mixture of $\mathrm{Ni}(\mathrm{OH})_{2}, \mathrm{CoO}$, and $\mathrm{ZnO}$ as the active material in a positive electrode to improve cycle life, utilization, HRD, and temperature range of the cell [92], and an optimized amount of electrolyte filling, $85 \%-97 \%$ of the available space in the cell to lower the cell pressure during charge [93].

\subsubsection{Japan Storage}

The GS-Japan Storage (Tokyo, Japan) Company was the first lead-acid manufacturer in Japan (1895). It formed a joint venture with the French Saft (Bagnolet, France), GS-Saft, producing Ni-Cd, and later $\mathrm{Ni} / \mathrm{MH}$ and Li-ion batteries in 1986. The company later merged into Yuasa in 2004. Some of their patent applications include: the addition of a metal layer next to a synthetic-resin-made container to suppress the self-discharge [94], a thermoplastic synthetic-resin-made relief valve with a melting point higher than $270{ }^{\circ} \mathrm{C}$ to improve the safety of the cell [95], addition of an Mn compound to the positive electrode to reduce the hydrogen reaction on the positive electrode surface and suppress the self-discharge of the cell [96], an activation scheme composed of electrical formation and heat storage to improve the HRD [97], and an increase in the negative electrode area to suppress pressure during charge [98].

\subsubsection{Shin-Kobe}

Shin-kobe Electric Machinery Co. (Tokyo, Japan) is a manufacturer of lead-acid, Ni/MH, and Li-ion batteries. Their Ni/MH product was sold through Hitachi with the trade name CellAce. In 2013, their business was merged into Hitachi Chemical (Tokyo, Japan). Shin-kobe's patent applications include: addition of conductive fibers in the negative electrode to reduce its electric resistivity [99], adding hydroxyl methyl cellulose as a ductile binder in the negative electrode to improve cell performance [100], a substrate fabrication method for mixing $\mathrm{MH}$ and Ni powder on the surface of polyurethane (PU) foam and removing the PU in a heated reduction atmosphere [101], addition of ethylene-vinyl acetate-acrylate copolymer, acrylate-styrene-alkyl acrylate copolymer, methylcellose, and nickel powder in the slurry for the negative electrode to improve the gas absorption ability [102], and addition of $\mathrm{CaCO}_{3}$ to reduce the oxygen evolution in the negative electrode during over-discharge (cell reversal) [103].

\subsubsection{Other Battery Manufacturers}

Other than those consumer battery manufacturers introduced above, there are companies focused on other markets. For example, PEVE currently produces the highest Ah amount of batteries, supporting the HEV business of Toyota. All their inventions are related to battery pack assembly, battery management systems (BMS), and testing. Examples include: a failure sensing mechanism [104], a cooling controlling method [105], a current detection method [106], an electric current leakage detecting device [107], a voltage measuring method [108] in the battery pack, a state-of-charge (SOC) estimation method [109,110], a testing method for relay contact welding [111], BMS for vehicles [112], and an activation algorithm [113]. Kawasaki Heavy Industry (Kyoto, Japan) developed a GIGACELL high-power Ni/MH battery for stationary and locomotive applications [114]. They have filed patent applications to cover: 3D batteries [115], addition of conductive fibers, carbon particles, Ni foil, Ni-plates fiber, etc. to increase the conductivity and connection of the negative electrode in $\mathrm{Ni} / \mathrm{MH}$ batteries [116], use of fibrous $\mathrm{MH}$ alloys in the negative electrode to improve charge and discharge rate capability [117], a fold design for electrode stacking (the basis of GIGACELL) [118-120], design of a battery charger for railroad applications [121], an SOC estimation algorithm [122], a pressure-regulating device [123], a battery module [124], and a battery system [125]. Honda Denki (Tokyo, Japan) developed a flooded type of long-lasting Ni/MH battery (Table 2), but they did not file any patent application for technology originating from the flooded Ni-Fe battery [126]. Varta Battery filed a Japanese patent application about adding Mn-oxide in the 
positive electrode [127]. Saft, a French company, also filed a Japanese patent application on a C14 Laves phase alloy for negative electrodes [128]. Samsung Display Devices (Yongin-Gun, Korea) filed a Japanese patent application about adding an insulating layer at the edge of one electrode to prevent short-circuit [129]. Ovonic Battery Company also has a few Japanese patent applications covering disordered $\mathrm{AB}_{2}$ [130-134], MgNi-based [135-137] MH alloys, a disordered positive electrode [138-140], and a mono-block design [141]. Its parent company, Energy Conversion Devices Inc. (Troy, MI, USA) also filed a patent application regarding a dry compaction method for making a negative electrode belt [142].

Table 2. Characteristics of the flooded type Ni/MH batteries made by Honda Denki. Information from their brochure.

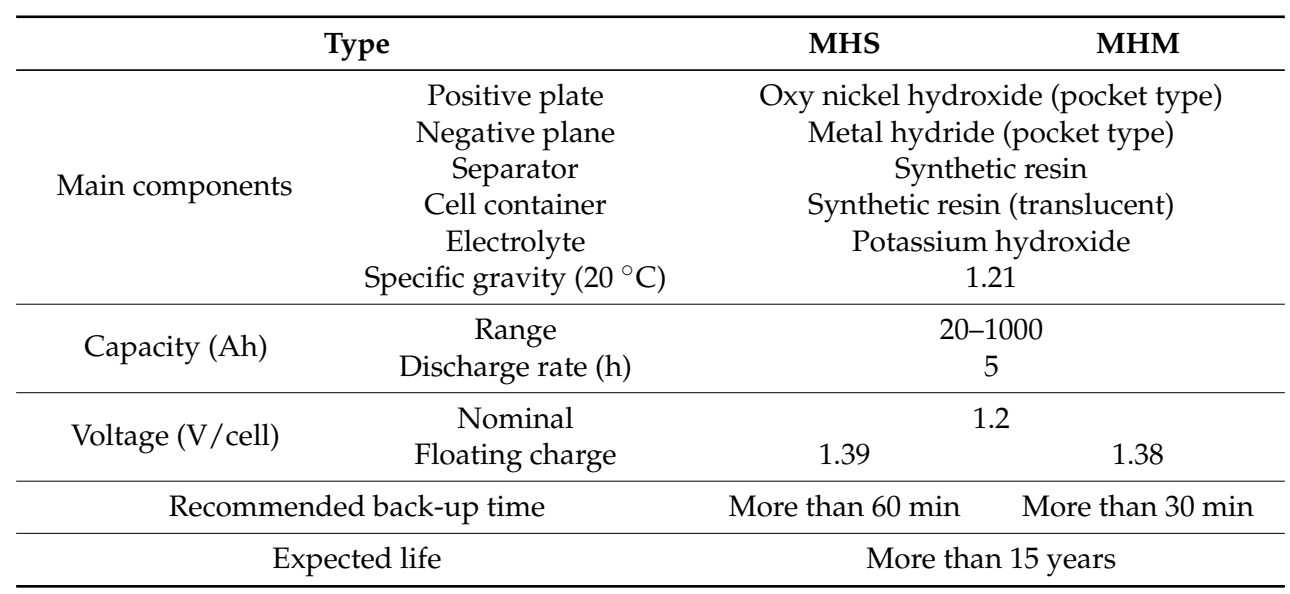

\subsection{Component Suppliers}

\subsubsection{Tanaka Chemical Co.}

Tanaka Chemical Co. (Fukui, Japan) is the main producer of spherical $\mathrm{Ni}(\mathrm{OH})_{2}$ that can act as positive electrode active materials. In the early days, Tanaka monopolized the spherical $\mathrm{Ni}(\mathrm{OH})_{2}$ market, but has now been replaced by many Chinese manufacturers. In 1996, Tanaka filed five patent applications covering: surface coating of $\alpha-\mathrm{Co}(\mathrm{OH})_{2}$ [143] or $\beta-\mathrm{Co}(\mathrm{OH})_{2}[144]$ and conversion into $\gamma$-CoOOH with a high conductivity on the surface of $\mathrm{Ni}(\mathrm{OH})_{2}$, addition of salts from sulfuric acid, nitric acid, boric acid, and phosphoric acid to increase the solubility of $\mathrm{Co}(\mathrm{OH})_{2}$ in the electrolyte [145], a co-precipitation of hydroxide with $\mathrm{Ni}, \mathrm{Co}, \mathrm{Zn}, \mathrm{Y}$ (or Cd) as the positive electrode active material [146], and an increase in the adhesion of $\mathrm{Co}$ coating to the $\mathrm{Ni}(\mathrm{OH})_{2}$ spherical particles to prevent peeling [147]. In 1998, Tanaka filed another three patent applications covering: an auxiliary conductive binder addition into the positive electrode paste with $\alpha-\mathrm{Co}(\mathrm{OH})_{2}$ [148], an additional coating of $\mathrm{Ni}$ or $\mathrm{Ni}$ alloy on the $\mathrm{Co}(\mathrm{OH})_{2}$ coating on the $\mathrm{Ni}(\mathrm{OH})_{2}$ particles [149], and an oxidation process for $\mathrm{Co}(\mathrm{OH})_{2}$ coating in an oxidation environment with heat to save the cost [150].

\subsubsection{Mitsui Metal}

Mitsui Bussan Metals Co. (Tokyo, Japan) was the major $\mathrm{AB}_{5} \mathrm{MH}$ alloy producer that has used the conventional induction melting and casting method since the debut of $\mathrm{Ni} / \mathrm{MH}$ battery. It was the major $\mathrm{AB}_{5} \mathrm{MH}$ alloy supplier to Matsushita. Patent applications from Mitsui are all about $\mathrm{AB}_{5} \mathrm{MH}$ alloys which include: a columnar structure-dominate $(>80 \%)$ of $\mathrm{AB}_{5}$ ingot which facilitates the early pulverization [151], a wet crushing and grinding process for $\mathrm{AB}_{5}$ ingots [152], addition of Mo or $\mathrm{Cr}$ in the $\mathrm{AB}_{5}$ formula to increase the capacity of the alloy [153], partial replacement of rare earth elements with Ca to reduce the cost [154], quick quench plus annealing to make alloys with heterogeneous strain to improve the cycle life [155], addition of $\mathrm{Cu}$ and $\mathrm{B}$ in the alloy formula to improve HRD of the cell [156], a low-cost $\mathrm{Cu}$-containing $\mathrm{AB}_{5} \mathrm{MH}$ alloy with the lattice parameter $c$ between $4.062 \AA$ and 
$4.069 \AA$ [157], an over-stoichiometric MH alloy with B/A between 0.05 and 5.25 and a lattice parameter $c$ greater than $4.049 \AA$ [158], and a low- $\mathrm{Co} \mathrm{Cu}(\mathrm{Fe})$-containing $\mathrm{AB}_{5} \mathrm{MH}$ alloy with the lattice parameter $c$ greater than $4.042 \AA[159]$.

\subsubsection{Santoku Metal}

Santoku Metal Industry Co. (Kobe, Hyogo, Japan) manufactures both MH alloy and NdFeB (for permanent magnetic applications) based on rare-earth elements using a strip-casting method. In 2000, the company name was changed to Santoku Corporation. Currently, the main production facility for making MH alloys was moved to its joint venture in China, Baotou Santoku Battery Materials Co. (Baotou, Inner Mongolia, China). Santoku's patent applications are also all about the development of MH alloys, such as: a method of making rare-earth-containing hydrogen storage alloy (filed in 1983) [160], an asymmetric alloy microstructure in the network segregation of $\mathrm{AB}_{5} \mathrm{MH}$ alloy [161], a storage method for rare-earth-containing alloys [162], a rapid quench with cooling rate between $1000{ }^{\circ} \mathrm{C} \cdot \mathrm{s}^{-1}$ and $10,000{ }^{\circ} \mathrm{C} \cdot \mathrm{s}^{-1}[163]$, and a strip-casting method of making rare-earth-containing alloy (Figure 11) [164].

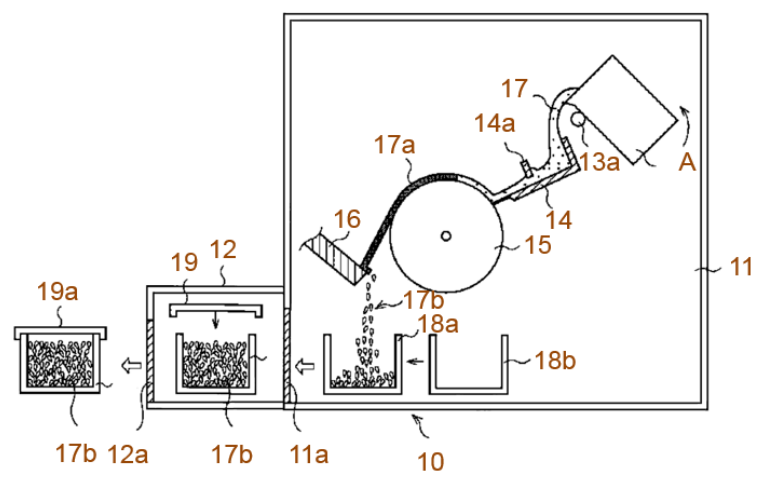

Figure 11. Schematic diagram of a strip-casting system patented by Santoku and widely adapted in China for production of Nd-B-Fe magnetic materials and $\mathrm{AB}_{5} \mathrm{MH}$ alloys. The numbers indicate the following: 10: manufacturing system; 11: the first chamber; 12: the second chamber; 11a and 12a: shutter valve; 13: induction furnace; 14: tundish; 15: rotating roll; 16: alloy crushing board; 17a: ribbons; 17b: crushed powder; 18, 18a and 18b: containers; 19 and 19a: top cover of a water-cooled container. Reproduced from [164].

\subsubsection{Japan Metals \& Chemicals Co.}

In the early days, Japan Metals \& Chemicals Co. (JMC, Tokyo, Japan) worked closely with the battery manufacturer Toshiba. With the ownership of Takasaki Plant transferring from Toshiba to Sanyo and finally to FDK, JMC remained the largest MH alloys supplier in Japan. With a proprietary fabrication method, JMC is one of the few $\mathrm{MH}$ alloy suppliers that can produce $\mathrm{A}_{2} \mathrm{~B}_{7}$-related $\mathrm{MH}$ alloy in a full production scale (the other one is Santoku), which is a key component used in the eneloop low self-discharge consumer and GIGACELL stationary batteries. Besides battery materials, JMC also serves as the pioneering and continuing contributor in the gaseous hydrogen storage application of $\mathrm{MH}$ alloys. The first patent application filed by JMC in 1980 on MH alloys is about a fabrication method of TiFe binary alloy [165]. Later patent applications extended to the quaternary alloy system Ti-Fe-Zr-(Nb or $\mathrm{Mn})$ [166]. The first $\mathrm{AB}_{5} \mathrm{MH}$ alloy patent application filed in 1986 by JMC was regarding the addition of $\mathrm{Co}, \mathrm{Al}$, and $\mathrm{Sn}$ to reduce the hysteresis in the pressure-concentration-temperature absorption and desorption isotherms [167]. In 1987, JMC also patented a precipitation method of making $\mathrm{Ni}(\mathrm{OH})_{2}$ [168]. JMC filed a La-rich $\mathrm{AB}_{5} \mathrm{MH}$ alloy composition with $\mathrm{Ni}, \mathrm{Co}, \mathrm{Mn}$, and $\mathrm{Al}$ in 1993 [169]. Porous 3D-foam substrates made from $\mathrm{Ni}$ were proposed as substrates for both the positive and negative electrodes [170]. A patent application about a recovery methodology for Ni/MH battery scrap was filed in 1994 [171]. 
Other patent applications filed by JMC include: the use of Ag-plated Ni-foam as substrate to improve corrosion resistance [172], an Mg-Y MH alloy [173], an Fe-containing over-stoichiometry $\mathrm{AB}_{5} \mathrm{MH}$ alloy [174], a gas atomization method for acid or alkaline solutions [175], a pre-oxidation by $\mathrm{CO}_{2}$ for a freshly ground $\mathrm{MH}$ alloy [176], an $\mathrm{MgNi}_{2}$-based $\mathrm{MH}$ alloy [177], an acid etch plus alkaline solution activation method for MH alloys [178], a low-cost Ni-plated Fe alloy substrate [179], additives of Li composite for a spinel composite in a negative electrode to improve the cycle stability [180], an activation in alkaline solution with a complexing agent to reduce the pulverization rate [181], a two-phase $A_{5} M H$ alloys to reduce the pulverization rate [182], addition of $S n$ into the $A_{5}$ alloy formula and a lattice constant ratio $c / a$ between 0.8055 and 0.8070 [183], an $\mathrm{AB}_{5}$ with a Mg-rich secondary phase to maintain the HRD even with reduction in the Co content to save the cost [184], a multi-phase superlattice alloy with $>90 \%$ of $\mathrm{PuNi}_{3}, \mathrm{Ce}_{2} \mathrm{Ni}_{7}$, and $\mathrm{Pr}_{5} \mathrm{Co}_{19}$ phases and also an annealing condition of $1000{ }^{\circ} \mathrm{C}$ for $10 \mathrm{~h}$ to reduce the abundance of $\mathrm{AB}_{5}$ phase to $3 \%$ [185], a Ti-, $\mathrm{Zr}-$, and Hf- containing (0.2-1 at\% in A-site atoms) $\mathrm{AB}_{5} \mathrm{MH}$ alloy to increase capacity and cycle stability [186], an $\mathrm{AB}_{2}$ phase containing a superlattice $\mathrm{MH}$ alloy for better capacity, cycle life, and HRD [187], and a low-cost multi-phase $\mathrm{MH}$ alloy with $\mathrm{CaCu}_{5}(40-90 \mathrm{wt} \%), \mathrm{Ce}_{5} \mathrm{Co}_{19}(5-39 \mathrm{wt} \%)$, and $\mathrm{Pr}_{5} \mathrm{Co}_{19}(3-20 \mathrm{wt} \%)$ phases [188].

\subsubsection{Shin-Etsu Chemical}

Shin-Etsu Chemical (Tokyo, Japan) is a chemical company that has developed the various binder materials used in the paste electrode for $\mathrm{Ni} / \mathrm{MH}$ batteries. It filed a few patent applications for: a main binder material using hydroxyalkyl cellulose in the negative electrode [189], an organic binder with Sm-containing MH alloy [190], a negative electrode slurry with binders of hydroxyalkyl alkyl cellulose, alkyl cellulose, carboxymethyl cellulose, and water-soluble natural polysaccharide, and at least one selected from the group consisting of polyhydric alcohols having two or more hydroxyl groups in one molecule and water-soluble polyoles which are polyalkanol amines [191], a negative electrode slurry containing hydroxyalkyl alkyl cellulose, alkyl cellulose, carboxymetyl cellulose and water-soluble natural polysaccharides, and a denatured polyvinyl alcohol (PVA) [192]. Shin-Etsu is also an MH alloy supplier in Japan and filed an application for an MH alloy fabrication method without the need for annealing (Figure 12, [193]).

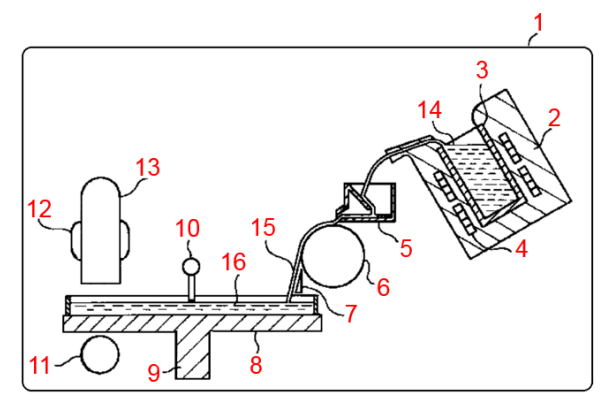

Figure 12. Schematic diagram of a strip-casting with the water-cooled pancake-mode system patented by Shin-Etsu. The numbers indicate 1: vacuum chamber; 2: induction furnace; 3: crucible; 4: radio frequency coil; 5: tundish; 6: cooling roll; 7: scrapper; 8: cooling table; 9: rotation shaft; 10: leveling arm; 11: gas inlet; 12: heat exchange fan; 13: fan duct; 14: melt; 15: alloy ribbons and flakes; and 16: alloy ribbons and flakes on a cooling table. Reproduced from [193].

\subsubsection{Other Suppliers}

As $\mathrm{Ni}(\mathrm{OH})_{2}$ suppliers, Ise Chemicals Corp. (Tokyo, Japan) has filed patent applications about a high density spherical particle from the co-precipitation of $\mathrm{Ni}, \mathrm{Zn}$, and $\mathrm{Co}[194,195]$ and a Co-compound-coated $\mathrm{Ni}(\mathrm{OH})_{2}$ [196] for use in the positive electrode. Sumitomo Chemical Co. (Tokyo, Japan) has also filed a patent application about high tap density $\mathrm{Ni}(\mathrm{OH})_{2}$ spherical 
particles [197] and another one about a sintered substrate for Ni-based positive electrodes [198]. Furukawa Electric (Tokyo, Japan) filed a patent application regarding the use of a gas atomization technique to make MH alloys (Figure 13, [199]). Chuo Denki Kogyo Co. (Myoko, Niigata, Japan) is an $\mathrm{MH}$ alloy supplier who filed patent applications involving a pre-oxidation environment including partial pressure of oxygen and some organic compounds during grinding [200], an acid etch process to facilitate the formation of an Ni-rich phase on the alloy surface [201], a hyper-stoichiometric $\mathrm{AB}_{5} \mathrm{MH}$ alloy with an improved high-rate and low-temperature performances [202], an acid etch in mineral acid solution with $\mathrm{Co}, \mathrm{Ni}, \mathrm{Fe}$, salt of rare earth elements or boric acid and other organic compounds [203]. Mitsubishi Metal Corp. (later changed name to Mitsubishi Materials Corp, Tokyo, Japan) filed patent applications about the use of $\mathrm{AB}_{2}$ [204-206], Mn-free [207] and S-, P-containing $\mathrm{AB}_{5}$ [208], and $A_{5} / A_{2} B_{7}$ mixed phase [209] MH alloys as the negative electrode active materials. Daido Steel (Nagoya, Aichi, Japan) filed three $\mathrm{AB}_{2} \mathrm{MH}$ alloy fabrication method patent applications [210-212]. TDK Corp. (Tokyo, Japan) filed two patent applications about using V-based body-centered-cubic (bcc) MH alloys as negative electrode materials [213,214] and one about arc melting together with melt-spinning to produce bcc-type MH alloys, which are very sensitive to the oxygen content from the oxide crucible (Figure 14, [215]). Japan Steel Works Ltd. (Tokyo, Japan) filed a patent application about an alkaline treatment for activation [216], a method using Mg-alloy [217], Nb-containing $\mathrm{AB}_{2}$ [218,219], Fe-containing [220], Mn-containing [221] and Mg-free [222] hyper-stoichiometric $\mathrm{A}_{2} \mathrm{~B}_{7}$ superlattice alloys for negative electrodes, and a cold crucible melting apparatus (Figure 15, [223]). Showa Denko (Tokyo, Japan) also patented a centrifugal casting method for making MH alloys (Figure 16, [224]). Sumitomo Metal Mining Co. (Tokyo, Japan), a major $\mathrm{Ni}(\mathrm{OH})_{2}$ supplier, filed patent applications regarding porous metal substrates [225], recycling from scrap of Ni/MH batteries [226,227], and a highly flexible metal form with resin fiber [228]. Katayama Special Industries, Ltd. (Osaka, Japan) is a supplier of a very flexible substrate for negative electrodes from power metallurgical processes [229]. The company also filed a patent application to cover the areas of a reinforced can structure with a hard layer to decrease the contact resistance [230] and a wet-paste electrode fabrication method [231]. A special tri-layer with a punched resin plate in the middle was patented by Toyoda Automatic Loom Works Ltd. (now Toyota Industries Co., Kariya-shi, Aichi, Japan) to maintain electrolyte folding power [232]. Toyo Ink SC Holding Co. (Tokyo, Japan) filed a patent application of ink mixture for foil-shape Ni/MH batteries [233]. Japan Vilene Co. (Tokyo, Japan) is a major sulfonated separator supplier and they filed patent applications to cover a PVA sheet laminated with nonwoven fabric [234], a separator made of polyolefin fiber graphed with polypropylene and polyethylene [235], and a fabrication method for a separator with higher acid resistance [236]. A mechanical alloying apparatus using an attritor to prepare MH alloys was patented by Nasu Denki Tekko Co. (Tokyo, Japan, Figure 17 [237].)

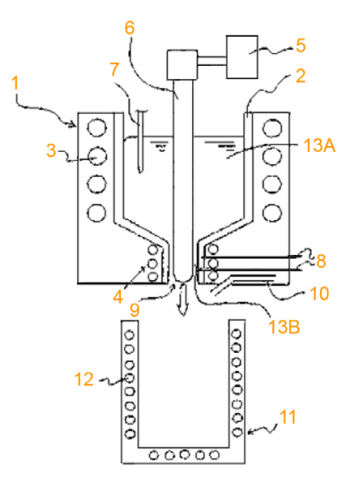

Figure 13. Schematic diagram of a gas atomization technique patented by Furukawa Electric with numbered parts, 1: melting furnace; 2: inner wall of crucible; 3 : upper induction coil; 4: lower induction coil; 5: motor; 6: stopper rod; 7 and 8: thermocouples; 9: slurry out; 10: gas nozzle; 11: water-cooled mold; 12: water pipe; 13A: melt; and 13B: partially solidified liquid. Reproduced from [199]. 


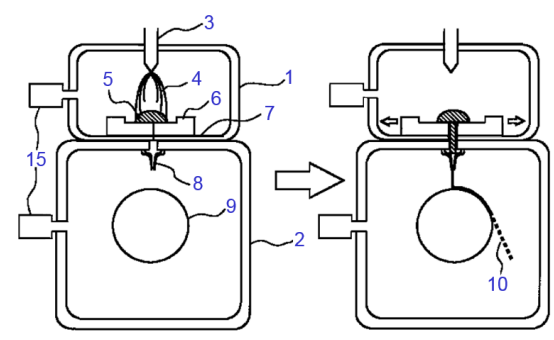

(a)

(b)

Figure 14. Schematic diagram of an arc melt and melt-spin preparation method for a body-centered-cubic (bcc) alloy by TDK Corp. with numbered parts, 1: melting chamber; 2: casting chamber; 3: arc electrode; 4: arc; 5: molten metal; 6: hearth; 7: bottom plate; 8: nozzle; 9: rotary roll; 10: ribbon; 15: inert atmosphere providers during (a) melting and (b) casting. Reproduced from [215].

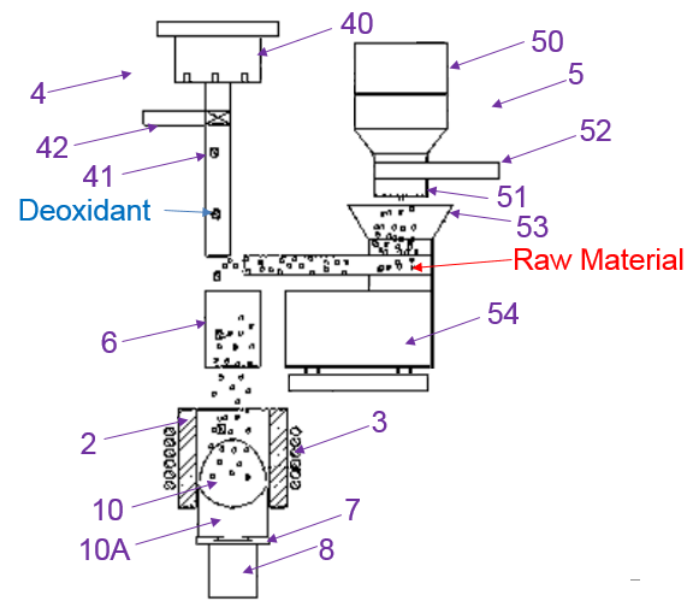

Figure 15. Schematic diagram of a magnetic levitation (skull) melting method patented by Japan Steel Works. Raw material and deoxidant were fed into the top of the furnace. Parts labeled by numbers are; 2: smelter; 3: induction coil; 4: deoxidant dispatcher; 40: container; 41: fall tube; 42: gate valve; 5: raw material feeder; 50: container; 51: fall tube; 52: gate valve; 53: hopper; 54: vibration feeder; 6: mixing box; 7: bottom of smelter; 8: drawing mechanism; 10: molten metal; and 10A: lower part of molten metal. Reproduced from [223].

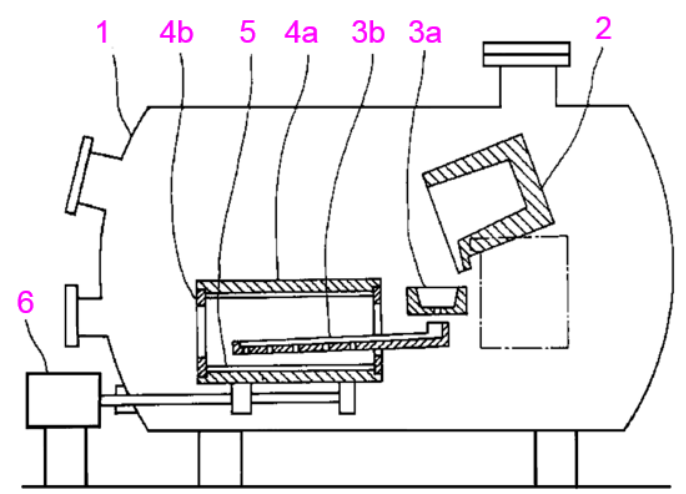

Figure 16. Schematic diagram of a centrifugal casting method patented by Showa Denko. Parts labeled by numbers are 1: vacuum chamber; 2 : induction furnace; $3 \mathrm{a}$ : primary stationary tundish; $3 \mathrm{~b}$ : secondary shuttling tundish; 4a: rotary cylindrical mold; 4b: end plate; 5: ingot; and 6: rotation drive. Reproduced from [224]. 


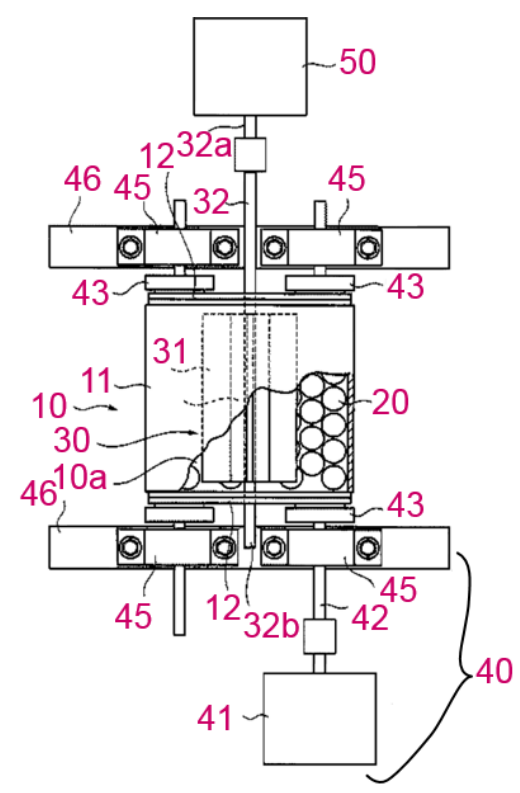

Figure 17. Schematic diagram of mechanical alloying by Nasu Denki Tekko Co. with numbered parts, 10: container; 11: drum section; 12: lateral section; 20: balls; 30: rotary body; 31: blade; 32: rotation axis; 40: slewing mechanism; 41: motor; 42: auxiliary roller; 43: transmission shaft; 45: holder; 46: base plate; and 50: motor. Reproduced from [237].

\subsection{Research Institutes}

\subsubsection{Industrial Research Institute}

The Japan Government Industrial Research Institute (ISI, Osaka, Japan) was established in 1918 and later merged into the National Institute of Advanced Industrial Science and Technology (AIST) in 2001. ISI made two remarkable contributions to the development of $\mathrm{Ni} / \mathrm{MH}$ technologies. In the early days, research works conducted by Osumi and his team [238-241] on the hydrogen storage properties of the mish-metal based $\mathrm{AB}_{5} \mathrm{MH}$ alloys paved the road for $\mathrm{Ni} / \mathrm{MH}$ battery commercialization. In 1993, a research team led by Kadir et al. [242] unveiled the potential of $\mathrm{Mg}-\mathrm{Ni}$-based superlattice alloys, which are the base of today's eneloop products. Examples of patent applications filed by ISI are: MH alloys with a Ni-rich surface made by electrical formation before the cells are assembled [243], a multi-phase $\mathrm{MH}$ alloy made from a Ti-V bcc solid solution and a TiNi phase [244], a multi-phase $\mathrm{MH}$ alloy made from $A B_{5}$ main phase and an $A B-A B_{3}$ minor phase, where $A$ is mainly Ti or $Z r$ and $B$ is mainly $\mathrm{Ni}$ [245], addition of a gas recombination electrode made from $\mathrm{Pd}$ and $\mathrm{Pt}$ to reduce the oxygen evolution potential [246], and an $\mathrm{AB}_{3} \mathrm{MH}$ alloy containing rare earth and alkaline earth elements [247].

\subsubsection{National Institute of Advanced Industrial Science and Technology}

AIST (Tsukuba, Ibaraki, Japan) was reorganized in 2001 as an incorporated administrative agency integrating 15 research institutes (including ISI) in Japan. Today, AIST still continues its support for the hydrogen storage and battery industries. AIST filed a patent application with Honda Motor using $\mathrm{TiFe}_{1-\mathrm{x}} \mathrm{Pd}_{\mathrm{x}}$ as a low-cost alternative negative electrode active material [248]. AIST also filed a patent application with JMC regarding a Laves phase based $\mathrm{AB}_{2} \mathrm{MH}$ alloy for use as a negative electrode active material [249]. In addition, AIST filed a patent application with Mitsubishi Kasei Corp. (Tokyo, Japan) about the use of a hypo-stoichiometric $\mathrm{AB}_{5} \mathrm{MH}$ alloy [250]. Together with Hitachi Maxell and Yuasa, AIST filed two patent applications about Mg-containing multi-phase MH alloys [251] and rectangular Ni/MH batteries from wound electrodes [252]. With Yuasa, AIST filed two patent applications for using $\operatorname{Pr}_{5} \mathrm{Co}_{19}$-structured [253] and layer-structured, along c-direction [254], $\mathrm{MH}$ alloys in the negative electrode. AIST also filed two patent applications with Asahi Kasei Corp. 
(Tokyo, Japan) about using a separator with a porous polyolefin surface with a pore size between $0.01 \mu \mathrm{m}$ and $1 \mu \mathrm{m}$ [255] and a pore size smaller than those in the positive and negative electrodes [256]. AIST and Sumitomo Electric Industries filed a patent application regarding the use of a Ni-coated non-woven fabric as the substrate to increase the loading of the negative electrode active materials [257]. AIST and Kawasaki Heavy Industry filed two patent applications about the use of a Ni-coated carbon fiber as the substrate and a final coating of an ion permeable polymer layer on top of the negative electrode [258] and a Co-free superlattice MH alloy [259]. Patent applications filed solely by AIST itself demonstrate the use of Mg-containing $\mathrm{MH}$ alloy in the $\mathrm{Ni} / \mathrm{MH}$ battery [260] and a porous foil substrate made from metal powder or fiber [261].

\subsubsection{Toyota Central R \& D Lab}

Toyota Central Research \& Development Laboratories, Inc. was established in 1960 in Nagakute-Shi, Aichi, Japan. It has approximately 1000 researchers working on resource conservation, energy conservation, environmental preservation, and safety. This company has been very active in the research of hydrogen storage alloys and fuel cell applications. Their patent applications in the field of $\mathrm{Ni} / \mathrm{MH}$ batteries include: a surface treatment involving $\mathrm{HF}$ and $\mathrm{NH}_{4} \mathrm{~F}$ mixed solution [262] and stream [263] to activate $\mathrm{MH}$ alloys, a porous metallic film on the substrate to suppress the deformation of the electrode [264], a high tap density positive material [265], a surface to reduce hydrogen evolution during over-charge [266], a conductive powder in the negative electrode to improve the HRD [267], a positive electrode suitable for high-temperature applications [268], a method of suppressing or preventing memory effects by adding an anion exchange membrane to the anode [269].

\subsubsection{Other Research Institutes in Japan}

Japan Aerospace Exploration Agency (JAXA, Tsukuba, Ibaraki, Japan) has described a hydrophobic metal sponge layer inside a button cell as a gas recombination center and the patent belongs to Toshiba [270]. Institute of Energy Engineering Inc. (Tokyo, Japan) offered a solution to cool down large-format batteries by inserting coolant-flowing channels inside the battery [271]. Imura Materials Development Institute (Kariya, Aichi, Japan) filed patent applications regarding fabrication of $\mathrm{Mg}-\mathrm{Cu}$ composites [272] and $\mathrm{V}-(\mathrm{Ta}, \mathrm{Nb})(\mathrm{Cr}, \mathrm{Mn})$ [273] materials for hydrogen storage applications, and V-based bcc [274], Ti-V solid solution bcc [275], bcc-TiNi multi-phase [276] alloys for battery applications. Jointly with AIST, Imura also filed a patent application about a deoxidation process for V-raw materials [277]. The International Center for Environmental Technology Transfer (ICETT, Yokkaichi, Mie, Japan) was established in 1990 to coordinate efforts from industry, academia, and the government to solve pollution issues. It filed two patent applications with GS Yuasa for the use of $\mathrm{LiOH}$ as an additive in the electrolyte to prolong the cycle life and improve the HRD performance [278] and a current-collector design to reduce internal resistivity [279].

\subsection{Analysis}

From the Japanese Patent Applications reviewed above, it is clear that scientists and engineers in Japan contributed a large amount of efforts in the composition fine-tuning, manufacturing process improvement, and special applications. Their research covers from raw materials, active ingredients, additives, electrodes, cells, modules, to the entire battery-powered systems. These patented approaches may not be adopted in today's commercial products, but they remain as alternative choices when the demand or market situation changes. It is, thus, important to keep track of these possible solutions to the past or current problems. Compared to the Japanese Patent Applications, those filed in the US tend to be more fundamental and less specific. For example, the methodologies to improve ultra-low-temperature performance of the Ni-MH battery can be found in US Patent 7,344,677 describing a surface oxide structure allowing electrolyte transportation at low-temperature [280] and a Japanese Patent Application filing the use of $\mathrm{TeO}_{2}$ in the electrolyte [80]. The US Patent is less material-specific and provides a general direction for the improvement. Therefore, our suggestion 
is that, while the Japanese Patent Applications provide more direct solutions to engineers working in the field, the US Patents (and applications) are better guides for scientists looking for new ideas and approaches.

\section{Conclusions}

We have listed the key Japanese patent applications from the major $\mathrm{Ni} / \mathrm{MH}$ battery makers and component suppliers in Japan, covering a variety of topics, including the composition and process design of the active materials and additives, electrode fabrication process, cell assembly (Figure 18), and battery system integration. In addition, we also use two examples to demonstrate the continuity and the competition of the research in areas of additives to the negative electrode associated with the superlattice alloys and the apparatus of $\mathrm{MH}$ alloy fabrication using different methods. Compared to the US Patents, the Japanese patent applications usually describe a specific composition formula range or detailed description of the design with narrower scope and less elaboration. However, they are described in full detail and are easier to interpret than the US Patents.

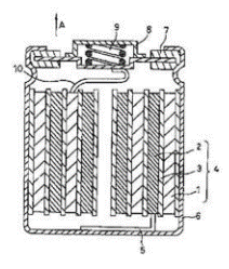

(a)

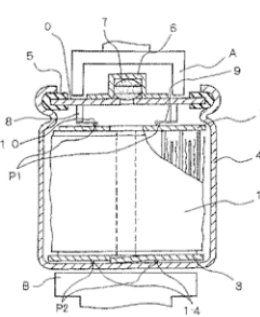

(b)

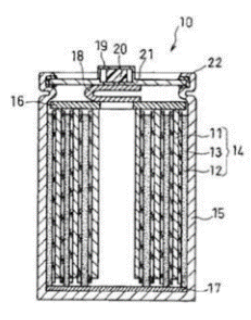

(c)

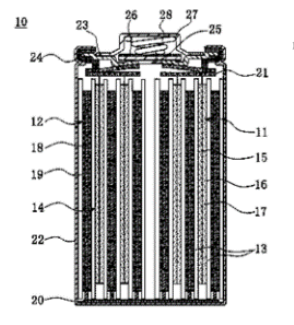

(d)

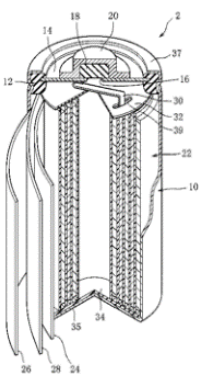

(e)

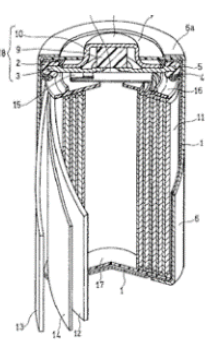

(f)

Figure 18. Schematic diagrams of (a) a single tap (10) design from Sanyo [21]; (b) a multiple welding spots (P) design from Yuasa [281]; (c) an addition of current-collect plate (16) design from Panasonic [282]; (d) a foldable end-plate design (21) from FDK [283]; (e) an insulating plate (32) design from FDK [77]; and (f) a positive electrode current collector (15) design from Panasonic [284].

Acknowledgments: Authors appreciate assistance from Su Cronogue and Tiejun Meng.

Author Contributions: Taihei Ouchi collected and analyzed the information. Kwo-hsiung Young prepared the manuscript and drawings. Dhanashree Moghe helped in information analysis and manuscript preparation.

Conflicts of Interest: The authors declare no conflict of interest.

\section{Abbreviations}

$\begin{array}{ll}\text { Ni/MH } & \text { Nickel/metal hydride } \\ \text { HEV } & \text { Hybrid electric vehicle } \\ \text { AIST } & \text { Agency of Industrial Science and Technology } \\ \text { PEVE } & \text { Panasonic EV Energy (now Primearth EV Energy) } \\ \text { MH } & \text { Metal hydride } \\ \text { PTFE } & \text { Polytetrafluoroethylene } \\ \text { HRD } & \text { High-rate dischargeability } \\ \text { XRD } & \text { X-ray diffractometer } \\ \text { PU } & \text { Polyurethane } \\ \text { BMS } & \text { Battery management system } \\ \text { JMC } & \text { Japan Metals \& Chemicals Co. } \\ \text { PVA } & \text { Polyvinyl alcohol } \\ \text { ISI } & \text { Industrial Research Institute } \\ \text { bCC } & \text { Body-centered-cubic } \\ \text { JAXA } & \text { Japan Aerospace Exploration Agency } \\ \text { ICETT } & \text { International Center for Environmental Technology Transfer }\end{array}$




\section{References}

1. Global xEV Batteries Market: Key Research Findings 2014; Yano Research Institute: Tokyo, Japan, 2015.

2. Chang, S.; Young, K.; Nei, J.; Fierro, C. Reviews on the U.S. Patents regarding nickel/metal hydride batteries. Batteries 2016, 2. [CrossRef]

3. Webpage of Japan Platform for Patent Information. Available online: https://www4.j-platpat.inpit.go.jp/ eng/tokujitsu/tkbs_en/TKBS_EN_GM101_Top.action (accessed on 24 June 2016).

4. Panasonic EVOLTA NiMH. Available online: http://www.panasonic.com/global/consumer/battery/ panasonic_rechargeable.html (accessed on 9 April 2016).

5. Yamamoto, T.; Komori, K.; Suzuki, G.; Yamaguchi, S.; Kimura, T.; Ikoma, M.; Toyoguchi, Y. Production of Hydrogen Storage Alloy Powder. Jpn. Pat. Appl. H07-048602, 21 February 1995.

6. Yamamoto, T.; Tsuji, M.; Komori, K.; Suzuki, G.; Yamaguchi, S.; Toyoguchi, Y. Production of Hydrogen Storage Alloy Powder and Nickel-Hydrogen Battery. Jpn. Pat. Appl. H07-054016, 28 February 1995.

7. Furuike, K.; Ebihara, T.; Tanaka, A.; Yuasa, K.; Kaiya, H. Sealed Alkaline Battery. Jpn. Pat. Appl. H9-213319, 15 August 1997.

8. Izumi, Y.; Moriwaki, Y.; Yamashita, K.; Tokuhiro, T. Nickel-Hydrogen Storage Battery. Jpn. Pat. Appl. H09-231969, 5 September 1997.

9. Imamura, K.; Oomura, A.; Yuasa, K.; Kaiya, H. Hydrogen Storage Alloy Powder for Battery and Manufacture Thereof. Jpn. Pat. Appl. H09-245784, 19 September 1997.

10. Hayashi, S.; Tomioka, K.; Morishita, N.; Ikeyama, S.; Ikoma, M. Nickel Positive Electrode for Alkaline Storage Battery and Nickel Hydrogen Storage Battery Using This Electrode. Jpn. Pat. Appl. H10-064537, 6 March 1998.

11. Hayashi, S.; Tomioka, K.; Morishita, N.; Ikoma, M. Nickel Positive Electrode and Nickel-Hydrogen Storage Battery Using It. Jpn. Pat. Appl. H10-106556, 24 April 1998.

12. Yuasa, S.; Komori, K.; Matsuda, H.; Ikoma, M. Alkaline Storage Battery. Jpn. Pat. Appl. H10-106620, 24 April 1998.

13. Kasahara, H.; Yao, T.; Dansui, Y.; Konishi, H. Alkaline Storage Battery and Manufacture of Its Positive Electrode Active Material. Jpn. Pat. Appl. H11-185749, 9 July 1999.

14. Kasahara, H.; Yao, T.; Suzuki, T.; Masui, M.; Konishi, H. Nickel-Hydrogen Storage Battery for Backup Power Supply. Jpn. Pat. Appl. H11-329481, 30 November 1999.

15. Kikuyama, T.; Ebihara, T.; Miyahara, A.; Ou, S.; Yuasa, K. Hydrogen Storage Alloy for Battery, Its Manufacture and Alkaline Storage Battery Using It. Jpn. Pat. Appl. H11-339793, 10 December 1999.

16. Ebihara, T.; Kikuyama, T.; Miyahara, A.; Ou, S.; Yuasa, K. Alkaline Storage Battery, Hydrogen Storage Alloy Electrode and Its Manufacture. Jpn. Pat. Appl. 2000-090920, 31 March 2000.

17. Sakai, T. Secondary Battery with Hydrogen Storage Alloys. In Hydrogen Storage Alloys_Fundamentals and Frontier Technology; Tamura, H., Ed.; NTS Inc.: Tokyo, Japan, 1998; p. 411.

18. Wikipedia, The Free Encyclopedia. Eneloop. Available online: https://en.wikipedia.org/wiki/Eneloop (accessed on 9 April 2016).

19. Yasuoka, S.; Magari, Y.; Murata, T.; Tanaka, T.; Ishida, J.; Nakamura, H.; Nohma, T.; Kihara, M.; Baba, Y.; Teraoka, H. Development of high-capacity nickel-metal hydride batteries using superlattice hydrogen-absorbing alloys. J. Power Sources 2006, 156, 662-666. [CrossRef]

20. Teraoka, H. Development of Low Self-Discharge Nickel-Metal Hydride Battery. Available online: http: / / www.scribd.com/doc/9704685/Teraoka-Article-En (accessed on 24 June 2016).

21. Takizawa, Y.; Ueda, T.; Kanekawa, I. Metal Hydride Storage Battery. Jpn. Pat. Appl. H05-242908, 21 September 1993.

22. Shiraiwa, S.; Ueda, T.; Takizawa, Y. Metal Hydride Battery. Jpn. Pat. Appl. H07-065825, 10 March 1995.

23. Yamawaki, A.; Nakahori, S.; Hamamatsu, T.; Baba, Y. Non-Sintered Nickel Electrode for Alkaline Storage Battery, Manufacture Thereof and Alkaline Storage Battery. Jpn. Pat. Appl. H08-148146, 7 June 1996.

24. Nogami, M.; Matsuura, Y.; Kimoto, M.; Higashiyama, N.; Tokuda, M.; Isono, T.; Yonezu, I.; Nishio, K. Hydrogen Storage Alloy Electrode for Alkaline Storage Battery. Jpn. Pat. Appl. H09-147903, 6 June 1997.

25. Ise, T. Metal Hydride Storage Battery. Jpn. Pat. Appl. H09-245782, 19 September 1997.

26. Niiyama, K.; Tokuda, M.; Satoguchi, K.; Yano, M.; Nogami, M.; Yonezu, I.; Nishio, K. Alkaline Storage Battery. Jpn. Pat. Appl. H10-021904, 23 January 1998. 
27. Satoguchi, K.; Tokuda, M.; Niiyama, K.; Yano, M.; Nogami, M.; Yonezu, I.; Nishio, K. Manufacture of Unsintered Nickel Electrode for Alkaline Storage Battery. Jpn. Pat. Appl. H10-188970, 21 July 1998.

28. Suzuki, S.; Tokuda, M.; Kimoto, M.; Yano, M.; Fujitani, S.; Nishio, K. Sealed Alkaline Storage Battery. Jpn. Pat. Appl. H10-214621, 11 August 1998.

29. Matsuura, Y.; Nogami, M.; Maeda, R.; Niiyama, K.; Yonezu, I.; Nishio, K. Hydrogen Storage Alloy Electrode for Alkaline Storage Battery, and the Alkaline Storage Battery Using Thereof. Jpn. Pat. Appl. H11-031504, 2 February 1999.

30. Kamiyoshi, K.; Ozaki, K.; Otsuki, K. Alkaline Storage Battery. Jpn. Pat. Appl. H09-213342, 15 August 1997.

31. Niiyama, K.; Yano, M.; Maeda, R.; Nogami, M.; Yonezu, I.; Nishio, K. Non-Sintered Nickel Electrode for Alkaline Storage Battery. Jpn. Pat. Appl. H09-259878, 3 October 1997.

32. Uenae, K. Hydrogen Storage Alloy Electrode and Alkaline Secondary Cell Using It. Jpn. Pat. Appl. H05-159798, 25 June 1993.

33. Horiie, H.; Nagai, T. Cylindrical Alkaline Secondary Battery. Jpn. Pat. Appl. H05-226001, 3 September 1993.

34. Hattori, H.; Kido, H.; Ishida, O.; Nagai, T. Alkaline Secondary Battery. Jpn. Pat. Appl. H05-290841, 5 November 1993.

35. Edamoto, T.; Wada, S. Nickel Hydride Secondary Cell. Jpn. Pat. Appl. H08-050918, 20 February 1996.

36. Fukunaga, H.; Nagai, T. Hydride Secondary Battery. Jpn. Pat. Appl. H08-190931, 23 July 1996.

37. Fukunaga, H.; Tamakoshi, H.; Nagai, T.; Tateishi, S. Hydride Secondary Battery and Manufacture Thereof. Jpn. Pat. Appl. H10-040910, 13 February 1998.

38. Takai, M.; Fukunaga, H.; Nagai, T. Assembled Battery of Hydride Secondary Battery. Jpn. Pat. Appl. H10-208768, 7 August 1998.

39. Fukunaga, H.; Nagai, T. Closed Type Hydride Secondary Battery. Jpn. Pat. Appl. H11-149939, 2 June 1999.

40. Fukunaga, H.; Tamakoshi, H.; Fujimoto, Y.; Nagai, T. Hydride Secondary Battery and Its Manufacture. Jpn. Pat. Appl. 2000-149934, 30 May 2000.

41. Ono, H.; Tamakoshi, H.; Fukunaga, H.; Nagai, T. Alkaline Storage Battery. Jpn. Pat. Appl. 2000-353520, 19 December 2000.

42. Ono, H.; Tamakoshi, H.; Fukunaga, H.; Nagai, T. Alkaline Storage Battery. Jpn. Pat. Appl. 2000-353542, 19 December 2000.

43. Oshitani, M.; Yufu, H. Nickel Electrode for Alkaline Battery. Jpn. Pat. Appl. H01-272050, 31 October 1989.

44. GS Yuasa. ENiTIME: Sealed Nickel-Metal Hydride Rechargeable Battery. Available online: http://pdf. directindustry.com/pdf/gs-yuasa/enitime/12414-296249.html (accessed on 9 April 2016).

45. Tomita, M. Alkaline Battery. Jpn. Pat. Appl. S55-009354, 23 January 1980.

46. Watada, M.; Matsumura, Y.; Miyake, N.; Oshitani, M. Electrode for Alkaline Storage Battery and Alkaline Storage Battery Using This Electrode. Jpn. Pat. Appl. H06-314567, 8 November 1994.

47. Bougauchi, T.; Nakagawa, H.; Kishimoto, N.; Yamane, M. Nickel Electrode Plate and Manufacture Thereof and Alkaline Storage Battery Using It. Jpn. Pat. Appl. H07-114920, 2 May 1995.

48. Tani, A. Nickel-Hydrogen Storage Battery. Jpn. Pat. Appl. H08-115739, 7 May 1996.

49. Ito, T.; Harada, T.; Arahi, K.; Yufu, H. Forming Method of Sealed Alkaline Storage Battery. Jpn. Pat. Appl. H08-153543, 11 June 1996.

50. Furukawa, K.; Tanaka, T.; Onishi, M.; Oshitani, M. Alkaline Storage Battery. Jpn. Pat. Appl. H09-092279, 4 April 1997.

51. Tani, A.; Kurokuzuhara, M. Separator for Nickel-Hydrogen Storage Battery. Jpn. Pat. Appl. H10-031990, 3 February 1998.

52. Matsumura, Y.; Tanaka, T.; Kurokuzuhara, M.; Tani, A.; Watada, M.; Oshitani, M. Sealed Nickel-Hydrogen Storage Battery. Jpn. Pat. Appl. H10-074536, 17 March 1998.

53. Kanemoto, M.; Kodama, M.; Kurokuzuhara, M. Hydrogen-Storing Alloy Electrode and Nickel Hydrogen Battery Using Same. Jpn. Pat. Appl. 2001-283854, 12 October 2001.

54. Kanemoto, M.; Kodama, M.; Kurokuzuhara, M.; Watada, M. Hydrogen Storage Alloy Electrode. Jpn. Pat. Appl. 2002-042800, 8 February 2002.

55. Kanemoto, M.; Kurokuzuhara, M.; Kodama, M.; Sakamoto, K.; Watada, M. Hydrogen Occlusion Alloy Powder, Hydrogen Occlusion Alloy Electrode, and Nickel-Hydrogen Storage Battery Using the Same. Jpn. Pat. Appl. 2004-124132, 22 April 2004. 
56. Hasebe, H.; Takeno, K.; Ikeda, K.; Sato, Y. Nickel Hydrogen Secondary Cell Module. Jpn. Pat. Appl. H05-036392, 12 February 1993.

57. Uchiyama, M.; Takeno, K. Alkaline Secondary Battery. Jpn. Pat. Appl. H07-211313, 11 August 1995.

58. Tsuruta, S.; Kono, R.; Kanda, M. Hydrogen Storage Alloy and Alkaline Secondary Battery. Jpn. Pat. Appl. H10-251782, 22 September 1998.

59. Kono, R.; Kanda, M. Hydrogen Storage Alloy, Cathode for Battery and Alkaline Secondary Battery. Jpn. Pat. Appl. H10-251791, 22 September 1998.

60. Mukai, K.; Ishizuka, S.; Takeno, K. Alkaline Secondary Battery. Jpn. Pat. Appl. H10-294106, 4 November 1998.

61. Hosobuchi, K.; Gama, M. Metallic Oxide Hydrogen Secondary Battery. Jpn. Pat. Appl. H07-326354, 12 December 1995.

62. Hayashida, H.; Kitayama, H.; Yamamoto, M.; Sakai, I.; Kono, R.; Yoshida, H.; Inaba, T.; Inada, S.; Kanda, M. Nickel-Hydrogen Secondary Battery. Jpn. Pat. Appl. H11-162460, 18 June 1999.

63. Kitayama, H.; Hayashida, H.; Yamamoto, M.; Sakai, I.; Kono, R.; Yoshida, H.; Inaba, T.; Inada, S.; Kanda, M. Nickel-Hydrogen Secondary Battery. Jpn. Pat. Appl. H11-162503, 18 June 1999.

64. Kono, R.; Sakai, I.; Yoshida, H.; Inaba, T.; Yamamoto, M.; Takeno, S. Hydrogen Storage Alloy and Secondary Battery. Jpn. Pat. Appl. 2000-073132, 7 March 2000.

65. Kono, R.; Sakai, I.; Yoshida, H.; Inaba, T.; Yamamoto, M. Hydrogen Storage Alloy and Secondary Battery. Jpn. Pat. Appl. 2000-265228, 26 September 2000.

66. Yoshida, H.; Yamamoto, M.; Sakai, I.; Inaba, T.; Takabayashi, J.; Irie, S.; Suzuki, H.; Takeno, K. Hydrogen Storage Alloy, Alkali Secondary Battery, Hybrid Car and Electric Vehicle. Jpn. Pat. Appl. 2002-069554, 8 March 2002.

67. Inaba, T.; Sakai, I.; Yoshida, H.; Takabayashi, J.; Yamamoto, M.; Suzuki, H.; Irie, S.; Takeno, K. Nickel Hydrogen Secondary Battery, Hybrid Car and Electric Vehicle. Jpn. Pat. Appl. 2002-083593, 22 March 2002.

68. Kawashima, F.; Sakamoto, T.; Arai, T. Hydrogen Storage Alloy and Nickel-Hydrogen Secondary Battery Using the Same. Jpn. Pat. Appl. 2002-105563, 10 April 2002.

69. Sakamoto, T.; Kawashima, F.; Arai, T. Hydrogen Storage Alloy, Its Production Method and Nickel-Hydrogen Secondary Battery Using the Same. Jpn. Pat. Appl. 2002-105564, 10 April 2002.

70. Sakai, I.; Inaba, T.; Yoshida, H.; Yamamoto, M.; Irie, S.; Suzuki, H.; Takeno, K. Hydrogen Storage Alloy, Secondary Battery, Hybrid Vehicle, and Electric Vehicle. Jpn. Pat. Appl. 2002-164045, 7 June 2002.

71. Saguchi, A.; Kihara, M.; Endo, T. Negative Electrode for Alkaline Secondary Battery, and Alkaline Secondary Battery Comprising the Negative Electrode. Jpn. Pat. Appl. 2012-134110, 12 July 2012.

72. Ishida, J.; Yasuoka, S.; Inui, H.; Kishida, K. Hydrogen Absorbing Alloy and Alkaline Storage Battery Manufactured Using the Hydrogen Absorbing Alloy. Jpn. Pat. Appl. 2012-174639, 10 September 2012.

73. Kihara, M.; Endo, T.; Sato, T.; Saguchi, A.; Wada, S.; Mugima, I.; Nakamura, T.; Asanuma, H.; Tamura, M. Negative Electrode for Nickel-Hydrogen Secondary Battery, and Nickel-Hydrogen Secondary Battery Using the Negative Electrode. Jpn. Pat. Appl. 2012-256522, 27 December 2012.

74. Kihara, M.; Takei, M.; Yamane, T. Nickel-Hydrogen Secondary Battery. Jpn. Pat. Appl. 2013-030345, 7 February 2013.

75. Ishida, J. Hydrogen Storage Alloy and Nickel-Hydrogen Secondary Battery Using the Same. Jpn. Pat. Appl. 2013-100585, 23 May 2013.

76. Ishida, J.; Yasuoka, S. Hydrogen Storage Alloy and Nickel-Hydrogen Secondary Battery Using the Same. Jpn. Pat. Appl. 2013-108105, 6 June 2013.

77. Ishida, J.; Kai, T. Hydrogen Storage Alloy and Nickel Hydride Secondary Battery Using the Hydrogen Storage Alloy. Jpn. Pat. Appl. 2014-145122, 14 August 2014.

78. Yamane, T.; Takei, M.; Imoto, Y.; Ito, T. Nickel Hydrogen Secondary Battery. Jpn. Pat. Appl. 2013-206867, 7 October 2013.

79. Kai, T.; Ishida, J. Nickel Hydrogen Secondary Battery and Negative Electrode for Nickel Hydrogen Secondary Battery. Jpn. Pat. Appl. 2014-026844, 6 February 2014.

80. Kai, T.; Ishida, J. Nickel Hydrogen Secondary Battery. Jpn. Pat. Appl. 2014-146557, 14 August 2014.

81. Kihara, M.; Saguchi, A.; Takei, M.; Ito, T.; Imoto, Y. Nickel Hydrogen Secondary Battery. Jpn. Pat. Appl. 2014-089879, 15 May 2014. 
82. Ishida, J.; Kai, T. Negative Electrode for Nickel-Hydrogen Secondary Battery, and Nickel-Hydrogen Secondary Battery Using the Same. Jpn. Pat. Appl. 2014-207086, 30 October 2014.

83. Sato, T. Nickel Hydrogen Storage Battery. Jpn. Pat. Appl. 2015-008107, 15 January 2015.

84. Kai, T.; Ishida, J. Nickel Hydrogen Secondary Battery. Jpn. Pat. Appl. 2015-103497, 4 June 2015.

85. Ishida, J.; Kai, T. Nickel Hydrogen Secondary Battery. Jpn. Pat. Appl. 2015-195108, 5 November 2015.

86. Takasu, D. Negative Electrode for Nickel Hydrogen Secondary Battery and Nickel Hydrogen Secondary Battery Using This Negative Electrode. Jpn. Pat. Appl. 2015-201334, 12 November 2015.

87. Ushara, I.; Sakai, T.; Ishikawa, H. The state of research and development for applications of metal hydrides in Japan. J. Alloys Compd. 1997, 253-254, 635-641.

88. Furukawa, A. Negative Electrode for Nickel-Hydrogen Secondary Battery. Jpn. Pat. Appl. H06-231758, 19 August 1994.

89. Furukawa, A. Nickel-Hydrogen Secondary Battery. Jpn. Pat. Appl. H06-231761, 19 August 1994.

90. Furukawa, A. Manufacture of Sealed Nickel-Hydrogen Secondary Battery. Jpn. Pat. Appl. H06-251800, 9 September 1994.

91. Furukawa, A. Production of Powdery Hydrogen Occluding Alloy for Negative Electrode of Nickel-Hydrogen Secondary Battery and Production of Negative Electrode for Nickel-Hydrogen Secondary Battery. Jpn. Pat. Appl. H06-279980, 4 October 1994.

92. Furukawa, A. Nickel-Hydrogen Secondary Battery. Jpn. Pat. Appl. H06-283195, 7 October 1994.

93. Furukawa, A. Sealed Nickel-Hydrogen Secondary Battery. Jpn. Pat. Appl. H06-283196, 7 October 1994.

94. Murata, T. Sealed Battery. Jpn. Pat. Appl. H05-021045, 29 January 1993.

95. Murata, T. Enclosed Type Nickel/Metal Hydride Storage Battery. Jpn. Pat. Appl. H05-041204, 19 February 1993.

96. Murata, T. Nickel-Metal Hydride Storage Battery. Jpn. Pat. Appl. H05-121073, 18 May 1993.

97. Shichimoto, K. Manufacture of Nickel Metal Hydride Cell. Jpn. Pat. Appl. H08-050919, 20 February 1996.

98. Nanamoto, K. Sealed Alkaline Storage Battery. Jpn. Pat. Appl. H09-199162, 31 July 1997.

99. Nomura, Y.; Ogura, T.; Kobayashi, K.; Tsuda, T. Hydrogen Storage Alloy Electrode and Manufacture Thereof. Jpn. Pat. Appl. H05-003029, 8 January 1993.

100. Konuki, T.; Kobayashi, K. Hydrogen Storage Alloy Electrode and Manufacture Thereof. Jpn. Pat. Appl. H06-163043, 10 June 1994.

101. Yamaguchi, T.; Watanabe, K.; Yoshida, M.; Kamigata, Y. Hydrogen Storage Electrode and Manufacture Thereof. Jpn. Pat. Appl. H08-050898, 20 February 1996.

102. Kobayashi, K.; Tamagawa, T. Hydrogen Storage Alloy Electrode and Nickel-Hydrogen Storage Battery. Jpn. Pat. Appl. H08-264175, 11 October 1996.

103. Minoura, S.; Kobayashi, K.; Ogura, T. Hydrogen Storage Alloy Electrode for Alkaline Storage Battery. Jpn. Pat. Appl. H10-092422, 10 April 1998.

104. Minamiura, K. Method and Device for Sensing Failure in Battery Pack System. Jpn. Pat. Appl. 2003-142165, 16 May 2003.

105. Minamiura, K. Controlling Method and Device for Cooling of Battery. Jpn. Pat. Appl. 2003-142166, 16 May 2003.

106. Yudahira, H. Battery Power Unit and Its Current Detecting Method. Jpn. Pat. Appl. 2003-168488, 13 June 2003.

107. Yudahira, H. Electric Leakage Detecting Device. Jpn. Pat. Appl. 2003-194870, 9 July 2003.

108. Yudahira, H. Voltage Measurement Device and Method, as well as Battery Pack System. Jpn. Pat. Appl. 2003-197273, 11 July 2003.

109. Murakami, T. Estimating Method of Polarized Voltage of Secondary Battery, Estimating Method and Device of Residual Capacity of Secondary Battery, as well as Battery Pack System. Jpn. Pat. Appl. 2003-197275, 11 July 2003.

110. Ueda, T.; Morishita, N.; Okawa, K.; Nakao, Y. Remaining Capacity Arithmetic Unit and Remaining Capacity Computing Method of Secondary Battery. Jpn. Pat. Appl. 2004-361313, 24 December 2004.

111. Morimoto, N. Testing Method for Relay Contact Welding in Battery Power Supply. Jpn. Pat. Appl. 2003-209907, 25 July 2003.

112. Nakanishi, T.; Torii, Y. Controller for Motorized Vehicle, Motorized Vehicle Equipped with It. Jpn. Pat. Appl. 2004-048937, 12 February 2004. 
113. Katakura, Y.; Kajikawa, T. Manufacturing Method of Nickel Metal Hydride Storage Battery. Jpn. Pat. Appl. 2010-153261, 8 July 2010.

114. Kawasaki Heavy Industries. Battery Energy Storage System-GIGACELL. Available online: https://global. kawasaki.com/en/energy/solutions/battery_energy/ (accessed on 9 April 2016).

115. Tsutsumi, K. Three-Dimensional Battery. Jpn. Pat. Appl. 2002-141101, 17 May 2002.

116. Tsutsumi, K.; Nishimura, K.; Mitsuta, S. Active Material for Battery and Its Manufacturing Method. Jpn. Pat. Appl. 2003-197187, 11 July 2003.

117. Tsutsumi, K.; Nishimura, K.; Mitsuta, S. Electrode Using Fibrous Hydrogen Storage Alloy, Battery Using Fibrous Hydrogen Storage Alloy and Electric Double Layer Capacitor. Jpn. Pat. Appl. 2004-022332, 22 January 2004.

118. Tsutsumi, K.; Nishimura, K. Battery. Jpn. Pat. Appl. 2008-041522, 21 February 2008.

119. Nishimura, K.; Tsutsumi, K. Square Battery. Jpn. Pat. Appl. 2010-129360, 10 June 2010.

120. Tsutsumi, K.; Nakoji, M.; Origuchi, T.; Ogawa, S.; Nakayama, N. Alkaline Storage Battery. Jpn. Pat. Appl. 2010-177071, 12 August 2010.

121. Ishida, T.; Sugiyama, S. Charger for Battery in Railroad Vehicle. Jpn. Pat. Appl. 2008-172857, 24 July 2008.

122. Koyano, K.; Miyamoto, Y.; Hayashi, M.; Sawai, T.; Yoshiyama, E.; Tsutsumi, K. Charged State Estimation Method and Device for Secondary Battery. Jpn. Pat. Appl. 2009-244057, 22 October 2009.

123. Nishimura, K.; Tsutsumi, K. Pressure Regulating Device of Battery. Jpn. Pat. Appl. 2009-301888, 24 December 2009.

124. Nishimura, K.; Takagaki, K.; Ugawa, K.; Ide, T. Battery Module. Jpn. Pat. Appl. 2013-168216, 29 August 2013.

125. Nishimura, K. Battery System. Jpn. Pat. Appl. 2013-143295, 22 July 2013.

126. Eguro, T.; Hashiguchi, J.; Koga, Y. Chemical Forming Method for High Energy Type Fe-Ni Battery. Jpn. Pat. Appl. H02-075168, 14 March 1990.

127. Lichtenberg, F.; Kleinsorgen, K.; Hofmann, G. Nickel/Metal Hydride Secondary Battery. Jpn. Pat. Appl. H07-211317, 11 August 1995.

128. Knosp, B.; Bouet, J.; Jordy, C.; Mimoun, M.; Gicquel, D. Material Capable of Hydrogenation for Negative Electrode of Nickel-Metal Hydride Storage Battery. Jpn. Pat. Appl. H08-017435, 19 January 1996.

129. Kang, S. Nickel Metal Hydride Storage Battery and Manufacture Thereof. Jpn. Pat. Appl. H09-171818, 30 June 1997.

130. Fetcenko, M.; Ovshinsky, S.; Chao, B.; Reichman, B. Improved Electrochemical Hydrogen Storage Alloy for Nickel Hydride Metal Battery. Jpn. Pat. Appl. 2000-144288, 26 May 2000.

131. Ovshinsky, S.; Fetcenko, M.; Im, J.; Young, K.; Chao, B.; Reichman, B. Hydrogen Occluding Material Having Abnormal Site Capable of Occluding Hydrogen at High Density. Jpn. Pat. Appl. 2002-088430, 27 March 2002.

132. Fetcenko, M.; Ovshinsky, S.; Chao, B.; Reichman, B. Improved Electrochemical Hydrogen Storage Alloy for Nickel Hydride Metal Battery. Jpn. Pat. Appl. 2002-088436, 27 March 2002.

133. Ovshinsky, S.; Fetcenko, M.; Im, J.; Young, K.; Chao, B.; Reichman, B. Hydrogen Storage Material Having High Density of Non-Conventional Usable Hydrogen Storing Sites. Jpn. Pat. Appl. 2002-241874, 28 August 2002.

134. Fetcenko, M.; Young, K.; Ovshinsky, S.; Reichman, B.; Koch, J.; Mays, W. Modified Electrochemical Hydrogen Storage Alloy Having Increased Capacity, Rate Capability and Catalytic Activity. Jpn. Pat. Appl. 2006-183148, 13 July 2006.

135. Ovshinsky, S.; Fetcenko, M. Secondary Battery Fabricated of Electrochemical Hydrogen Storage Alloy and Mg-Contained Base Alloy. Jpn. Pat. Appl. 2003-217578, 31 July 2003.

136. Ovshinsky, S.; Fetcenko, M.; Reichman, B.; Young, K.; Chao, B.; Im, J. Electrochemical Hydrogen Storage Alloy and Battery Fabricated from Magnesium-Containing Base Alloy. Jpn. Pat. Appl. 2003-247038, 5 September 2003.

137. Fetcenko, M.; Young, K.; Ouchi, T.; Reinhout, M.; Ovshinsky, S. Mg-Ni Hydrogen Storage Composite Having High Storage Capacity and Excellent Room Temperature Kinetics. Jpn. Pat. Appl. 2007-119906, 17 May 2007.

138. Fetcenko, M.; Fierro, C.; Ovshinsky, S.; Sommers, B.; Reichman, B.; Young, K.; Mays, W. Composite Positive Electrode Material and Its Manufacturing Method. Jpn. Pat. Appl. 2004-214210, 29 July 2004.

139. Ovshinsky, S.; Fetcenko, M.; Fierro, C.; Gifford, P.; Corrigan, D.; Benson, P.; Martin, F. High Performance Nickel Hydroxide Positive Electrode Electrode Material for Alkaline Rechargeable Electrochemical Battery. Jpn. Pat. Appl. 2006-054190, 23 February 2006. 
140. Fetcenko, M.; Fierro, C.; Ovshinsky, S.; Sommers, B.; Reichman, B.; Young, K.; Mays, W. Composite Positive Electrode Material and Method for Making Same. Jpn. Pat. Appl. 2010-282973, 16 December 2010.

141. Corrigan, D.; Gow, P.; Higley, L.; Muller, M.; Osgood, A.; Ovshinsky, S.; Payne, J.; Puttaiah, R. Monoblock Battery Assembly. Jpn. Pat. Appl. 2010-225591, 7 October 2010.

142. Wolff, M.; Nuss, M.; Fetcenko, M.; Lijoi, A. Continuous Manufacture of Hydrogen Storage Alloy Cathode. Jpn. Pat. Appl. H01-286255, 17 November 1989.

143. Imaizumi, J.; Kawasaki, Y.; Makino, T.; Iida, T. Alpha-Cobalt Hydroxide Layer-Coated Nickel Hydroxide for Alkaline Storage Battery and Manufacture Thereof. Jpn. Pat. Appl. H10-012236, 16 January 1998.

144. Imaizumi, J.; Kawasaki, Y.; Makino, T.; Iida, T. Beta-Cobalt Hydroxide Layer-Coated Nickel Hydroxide for Alkaline Storage Battery and Manufacture Thereof. Jpn. Pat. Appl. H10-012237, 16 January 1998.

145. Watada, M.; Oshitani, M.; Imaizumi, J.; Iida, T. Positive Electrode Active Material for Alkali Storage Battery, Its Manufacture and Positive Electrode for Alkali Storage Battery. Jpn. Pat. Appl. H10-027608, 27 January 1998.

146. Usui, T.; Makino, T.; Iida, T. Nickel Hydroxide for Alkaline Storage Battery and Manufacture Thereof. Jpn. Pat. Appl. H10-097856, 14 April 1998.

147. Watada, M.; Oshitani, M.; Imaizumi, J.; Iida, T. Positive Electrode Active Material for Alkaline Storage Battery and Manufacture Thereof, and Positive Electrode for Alkaline Storage Battery. Jpn. Pat. Appl. H10-188973, 21 July 1998.

148. Sakai, T.; Ishihara, K.; Imaizumi, J. Nickel Positive Electrode for Alkaline Secondary Battery. Jpn. Pat. Appl. 2000-077068, 14 March 2000.

149. Hosoe, A.; Imaizumi, J.; Iida, T. Nickel Positive Electrode Active Material for Alkaline Battery and Its Manufacture. Jpn. Pat. Appl. 2000-082463, 21 March 2000.

150. Tanaka, T.; Makino, T.; Iida, T. Manufacture of Positive Electrode Active Material for Alkaline Storage Battery. Jpn. Pat. Appl. 2000-268820, 29 September 2000.

151. Hirayama, S. Ingot for Hydrogen Storage Alloy Powder and Production of the Powder. Jpn. Pat. Appl. H04-358008, 11 December 1992.

152. Kuji, T.; Kitakado, M.; Yasuda, K.; Hanawa, K.; Nitta, S.; Dobashi, M. Method for Surface-Modifying Hydrogen Storage Alloy. Jpn. Pat. Appl. H07-316610, 5 December 1995.

153. Sasaki, M.; Hirayama, S.; Sumimoto, S. Hydrogen Storage Alloy and Its Production. Jpn. Pat. Appl. H09-031573, 4 February 1997.

154. Yasuda, K.; Nakayama, S. Hydrogen Storage Alloy. Jpn. Pat. Appl. H09-316573, 9 December 1997.

155. Sakaguchi, Y.; Nakayama, S.; Yasuda, K. Hydrogen Storage Alloy and Its Production. Jpn. Pat. Appl. H10-088261, 7 April 1998.

156. Sumimoto, S.; Sakai, M.; Uchiyama, A.; Hirayama, S.; Yasuda, K.; Nakayama, S.; Ebihara, T.; Yuasa, K. Hydrogen Storage Alloy and Electrode for Nickel-Hydrogen Battery Using It. Jpn. Pat. Appl. H10-152739, 9 June 1998.

157. Yasuda, K.; Hirayama, S.; Sakai, M.; Uchiyama, A.; Sakaguchi, Y.; Nakayama, S. Hydrogen Storage Alloy and Its Production. Jpn. Pat. Appl. H11-152533, 8 June 1999.

158. Yasuda, K.; Sakaguchi, Y.; Uchiyama, A.; Mukai, D.; Kikukawa, S. Hydrogen Storage Alloy and Its Manufacture. Jpn. Pat. Appl. 2000-234133, 29 August 2000.

159. Yasuda, K.; Sakaguchi, Y.; Kikukawa, S. Hydrogen Storage Alloy and Its Production Method. Jpn. Pat. Appl. 2001-348636, 18 December 2001.

160. Toma, H. Manufacture of Hydrogen Occluding Alloy of Rare Earth Metal-Nickel System. Jpn. Pat. Appl. S59-140301, 11 August 1984.

161. Yamamoto, K.; Miyake, Y.; Okada, T.; Kitatsume, N. Rare Earth-Nickel Hydrogen Storage Alloy Ingot and Its Production. Jpn. Pat. Appl. H05-320792, 3 December 1993.

162. Nishigaki, N.; Kitatsume, N.; Okada, T. Method for Preserving Rare Earth-Transition Metal Alloy. Jpn. Pat. Appl. H06-264102, 20 September 1994.

163. Kaneko, A. Rare Earth Metal-Nickel Based Hydrogen Storage Alloy and Its Production, and Cathode for Nickel-Hydrogen Secondary Battery. Jpn. Pat. Appl. H09-025529, 28 January 1997.

164. Yamamoto, K.; Okada, T. Production System of Alloy Containing Rare Earth Metal. Jpn. Pat. Appl. H09-155507, 17 June 1997.

165. Oota, T.; Yamaguchi, M.; Gashiyuu, S.; Noda, K.; Oku, K.; Konno, H.; Sasai, K. Hydrogen Occluding Alloy and Its Manufacture. Jpn. Pat. Appl. S56-136957, 26 October 1981. 
166. Noda, K.; Oku, K.; Konno, H.; Sasai, K.; Onoe, K.; Kashiyuu, S. Material for Storage of Hydrogen. Jpn. Pat. Appl. S57-075138, 11 May 1982.

167. Sasai, O.; Hayamizu, N.; Uotani, S. Hydrogen Storage Material. Jpn. Pat. Appl. S63-047345, 29 February 1988.

168. Uemura, M.; Yamamoto, I.; Tsubata, A.; Hayashi, T. Production of Nickel Hydroxide. Jpn. Pat. Appl. S64-042330, 14 February 1989.

169. Tomioka, H.; Matsubara, Y.; Hayamizu, N. Hydrogen Storage Alloy for Nickel/Hydrogen Battery. Jpn. Pat. Appl. H07-029570, 31 January 1995.

170. Uehara, H.; Ishikawa, H.; Nishida, J.; Sakuma, T.; Saito, N. Electrode for Alkaline Secondary Battery. Jpn. Pat. Appl. H07-073885, 17 March 1995.

171. Sasai, K.; Hayamizu, N.; Nakamura, M.; Kenmochi, Y.; Honda, J. Method for Recovering Valuable Material from Scrapped Nickel Hydrogen Occluding Alloy Secondary Battery. Jpn. Pat. Appl. H08-020825, 23 January 1996.

172. Kamisaka, K.; Nakayama, Y.; Nishida, J.; Igarashi, K.; Sakuma, T. Electrode Material of Silver Plated Nickel Based Porous Metal and Its Production. Jpn. Pat. Appl. H08-337894, 24 December 1996.

173. Takahashi, S.; Osawa, M.; Shimizu, H. Production of Magnesium-Yttrium Hydrogen Storage Alloy. Jpn. Pat. Appl. H09-125172, 13 May 1997.

174. Saito, N.; Takahashi, M.; Sasai, K. Hydrogen Storage Alloy for Battery. Jpn. Pat. Appl. H09-298059, 18 November 1997.

175. Obuchi, I.; Haraikawa, N. Production of Powder-Type Hydrogen-Storing Alloy. Jpn. Pat. Appl. H09-316505, 9 December 1997.

176. Sanoki, H.; Sugimoto, T.; Kudo, K. Method for Stabilizing Hydrogen Storage Alloy. Jpn. Pat. Appl. H10-195503, 28 July 1998.

177. Terashita, N.; Takahashi, M.; Kobayashi, K.; Sasai, K. Production of Amorphous Magnesium-Nickel Base Hydrogen Storage Alloy. Jpn. Pat. Appl. H11-269572, 5 October 1999.

178. Osawa, M.; Muromachi, N. Surface Treatment of Hydrogen Storage Alloy. Jpn. Pat. Appl. H11-335867, 7 December 1999.

179. Sakai, T.; Ikenaga, M.; Nishino, H.; Nishida, J. Alkaline Secondary Battery Electrode Substrate. Jpn. Pat. Appl. 2000-040516, 8 February 2000.

180. Yoshikawa, T.; Osawa, M.; Muromachi, N.; Endo, T.; Ogura, H. Negative Electrode for Secondary Battery. Jpn. Pat. Appl. 2000-090919, 31 March 2000.

181. Kobayashi, K.; Ogura, H.; Osawa, M.; Muromachi, N.; Harada, R.; Kimura, M.; Toyoshima, H. Hydrogen Storage Alloy Negative Electrode. Jpn. Pat. Appl. 2000-182608, 30 June 2000.

182. Saito, N.; Sugimoto, T.; Haneda, T.; Osawa, M.; Yoshikawa, T. Hydrogen Storage Alloy. Jpn. Pat. Appl. 2001-279354, 10 October 2001.

183. Saito, N.; Sugimoto, T.; Haneda, T.; Osawa, M.; Yoshikawa, T. Hydrogen Storage Alloy for Secondary Battery. Jpn. Pat. Appl. 2001-279355, 10 October 2001.

184. Terashita, N.; Ito, N.; Osawa, M.; Takahashi, S.; Tsunokake, S.; Hamura, K. Hydrogen Storage Alloy, Its Manufacturing Method and Nickel Hydrogen Secondary Battery. Jpn. Pat. Appl. 2007-056309, 8 March 2007.

185. Osawa, M.; Ito, N.; Terashita, N.; Takahashi, S.; Tsunokake, S. Hydrogen Storage Alloy and Nickel-Hydride Secondary Battery. Jpn. Pat. Appl. 2007-291474, 8 November 2007.

186. Kobayashi, K.; Takahashi, S.; Hayamizu, N. Secondary Battery Hydrogen Storage Alloy. Jpn. Pat. Appl. 2008-210809, 11 September 2008.

187. Terashita, N.; Osawa, M.; Kudo, K.; Soma, Y.; Tsunokake, S. Hydrogen Storage Alloy, and Nickel Hydrogen Secondary Battery. Jpn. Pat. Appl. 2012-067357, 5 April 2012.

188. Sakai, T.; Saito, M.; Mukai, T.; Tsunokake, S.; Osawa, M. Hydrogen-Storage Alloy, Hydrogen-Storage Alloy Electrode, and Nickel-Hydrogen Secondary Battery. Jpn. Pat. Appl. 2012-102343, 31 May 2012.

189. Fukui, I.; Kuribayashi, Y. Hydrogen Storage Alloy Electrode and Manufacture Thereof. Jpn. Pat. Appl. H08-088001, 2 April 1996.

190. Shintani, H.; Sugahara, Y. Hydrogen Storage Alloy-Containing Composition and Electrode Using It. Jpn. Pat. Appl. H08-329934, 13 December 1996.

191. Fukui, I. Manufacture of Hydrogen Storage Alloy Electrode. Jpn. Pat. Appl. H09-171820, 30 June 1997.

192. Fukui, I. Hydrogen Storage Alloy Electrode and Its Manufacture. Jpn. Pat. Appl. H11-329437, 30 November 1999. 
193. Kasashima, M.; Hashimoto, T.; Minowa, T. Apparatus for Producing Hydrogen-Storage Alloy and Production Thereof. Jpn. Pat. Appl. 2000-158098, 13 June 2000.

194. Komata, N.; Hibi, K.; Ohashi, S.; Aizawa, A.; Yaginuma, T. Production of Nickel-Containing Hydroxide. Jpn. Pat. Appl. H11-130441, 18 May 1999.

195. Hibi, K.; Wakai, E.; Oki, T.; Ban, S.; Furushima, K.; Shioda, M. Method for Producing Spherical High Density Nickel Hydroxide and Spherical High Density Nickel Hydroxide Powder for Anode Active Substance of Alkaline Secondary Battery. Jpn. Pat. Appl. 2003-002665, 8 January 2003.

196. Hibi, K.; Wakai, E.; Oki, T.; Furushima, K.; Ono, M.; Shioda, M. Nickel Positive Electrode Active Material for Alkaline Secondary Battery and Manufacturing Method of Cobalt Compound-Coated Nickel Hydroxide Particle. Jpn. Pat. Appl. 2003-157840, 30 May 2003.

197. Tsuji, S.; Son, H.; Uchida, Y. Spherical Nickel Hydroxide Powder and Method for Producing Same. Jpn. Pat. Appl. 2006-151795, 15 June 2006.

198. Matsubara, N.; Tanaka, M.; Ishikawa, S.; Shimizu, T.; Kitamura, N. Method for Manufacturing Nickel Sintered Substrate for Alkaline Storage Battery Positive Electrode and Nickel Sintered Substrate for Alkaline Storage Battery Positive Electrode. Jpn. Pat. Appl. 2015-198061, 9 November 2015.

199. Shibuya, S.; Hideno, A. Porous Hydrogen Storage Alloy. Jpn. Pat. Appl. H01-309937, 14 December 1989.

200. Kojima, Y.; Yamamoto, K.; Furukawa, S. Method of Producing Hydrogen Storage Alloy Powder. Jpn. Pat. Appl. 2004-169125, 17 June 2004.

201. Ishikawa, R.; Miyashita, T.; Yugamidani, M. Production of Hydrogen Occluding Alloy. Jpn. Pat. Appl. H06-088150, 29 March 1994.

202. Kojima, Y.; Ikeda, H.; Furukawa, S.; Sugiyama, K.; Kobayashi, N. Hydrogen-Storage Alloy, and Electrode for Nickel-Hydrogen Battery. Jpn. Pat. Appl. 2008-184660, 14 August 2008.

203. Hatakeyama, S.; Kojima, Y.; Miyashita, T.; Furukawa, S.; Sugiyama, K.; Tsuchiya, E.; Yabe, T. Manufacture of Hydrogen Storage Alloy Powder, and Ni-Hydrogen Battery. Jpn. Pat. Appl. H10-021907, 23 January 1998.

204. Doi, H.; Yabuki, T. Hydrogen Storage Ni-Base Alloy and Closed Type Ni-Hydrogen Storage Battery. Jpn. Pat. Appl. H02-111836, 24 April 1990.

205. Doi, H.; Yabuki, T. Hydrogen Storage Ni-Based Alloy and Closed Ni-Hydrogen Battery. Jpn. Pat. Appl. H02-194140, 31 July 1990.

206. Doi, H.; Yabuki, T. Hydrogen Storage Ni-Zr Series Alloy and Closed-Type Ni-Hydrogen Storage Battery. Jpn. Pat. Appl. H02-263944, 26 October 1990.

207. Nishikawa, S.; Takeshita, T. Hydrogen Storage Alloy Excellent in Corrosion Resistance and Negative Electrode for Secondary Battery Using It. Jpn. Pat. Appl. H05-156395, 22 June 1993.

208. Kita, K.; Sugawara, K.; Wada, M.; Murai, T.; Isobe, T. Hydrogen Storage Alloy Enabling High Rate Discharge of Battery. Jpn. Pat. Appl. 2000-345261, 12 December 2000.

209. Kita, K.; Sugawara, K.; Wada, M.; Murai, T.; Isobe, T. Hydrogen Storage Alloy. Jpn. Pat. Appl. 2000-073131, 7 March 2000.

210. Okochi, T.; Omori, H.; Kanekawa, A. Production of Hydrogen Storage Alloy. Jpn. Pat. Appl. H07-188799, 25 July 1995.

211. Nagase, I.; Shimizu, T.; Matsuyama, M. Production of Hydrogen Storage Alloy. Jpn. Pat. Appl. H07-305123, 21 November 1995.

212. Nagase, I.; Nishinakagawa, T.; Kimura, Y. Production of Hydrogen Storage Alloy Powder. Jpn. Pat. Appl. 2000-073101, 7 March 2000.

213. Matsukawa, A.; Odakawa, Y.; Fukuno, A.; Yamashita, S. Hydrogen Storage Alloy, Its Manufacture, and Secondary Battery. Jpn. Pat. Appl. 2000-265234, 26 September 2000.

214. Matsukawa, A.; Odakawa, Y.; Fukuno, A.; Yamashita, S. Hydrogen Storage Alloy, Its Manufacture, and Secondary Battery. Jpn. Pat. Appl. 2000-265235, 26 September 2000.

215. Sano, T.; Yamashita, S.; Cho, T.; Okada, M. Alloy Manufacturing Apparatus and Manufacturing Method of Hydrogen Storage Alloy. Jpn. Pat. Appl. 2002-331336, 19 November 2002.

216. Miyaki, T.; Terao, K.; Takahashi, T.; Kabutomori, T.; Wakizaka, Y. Manufacture of Hydrogen Storage Alloy Electrode. Jpn. Pat. Appl. H09-213317, 15 August 1997.

217. Miyaki, T.; Kabutomori, T.; Wakizaka, Y.; Morozumi, S.; Minegishi, T. Manufacture of Hydrogen Storage Alloy Electrode. Jpn. Pat. Appl. H08-203510, 9 August 1996.

218. Miyaki, T.; Kabutomori, T. Hydrogen Storage Alloy Electrode. Jpn. Pat. Appl. H09-027321, 28 January 1997. 
219. Kabutomori, T.; Miyaki, T.; Terao, K. Electrode of Hydrogen Storage Alloy. Jpn. Pat. Appl. H09-213320, 15 August 1997.

220. Miyaki, T.; Aoki, K.; Goto, T.; Ito, H. Hydrogen Storage Alloy, Producing Method Therefor and Hydrogen Storage Alloy Electrode Made of Same Alloy. Jpn. Pat. Appl. 2001-192756, 17 July 2001.

221. Miyaki, T.; Aoki, K.; Goto, T.; Ito, H. Hydrogen Storage Alloy, Producing Method Therefor and Hydrogen Storage Alloy Electrode Made of Same Alloy. Jpn. Pat. Appl. 2001-192758, 17 July 2001.

222. Miyaki, T.; Aoki, K.; Goto, T.; Ito, H. Hydrogen Storage Alloy, Producing Method Therefor and Hydrogen Storage Alloy Electrode Made of Same Alloy. Jpn. Pat. Appl. 2001-192757, 17 July 2001.

223. Aoki, K.; Muro, M.; Kakihara, H. Method of Producing Hydrogen Storage Alloy and Cold Crucible Melting Apparatus. Jpn. Pat. Appl. 2010-242145, 28 October 2010.

224. Hirose, Y.; Sasaki, S.; Hasegawa, H.; Hosono, U. Manufacture of Hydrogen Storage Alloy. Jpn. Pat. Appl. H09-180716, 11 July 1997.

225. Nishi, T.; Oka, Y. Metal Porous Body, Its Manufacture, and Battery Electrode Plate Using the Same. Jpn. Pat. Appl. H09-153365, 10 June 1997.

226. Fukui, A.; Imamura, M. Method for Recovering Valuable Metal from Scrap of Nickel Metal Hydride Secondary Battery. Jpn. Pat. Appl. 2003-041326, 13 February 2003.

227. Toki, N.; Kudo, T.; Asano, S. Method of Recovering Metal from Used Nickel-Metal Hydride Battery. Jpn. Pat. Appl. 2010-174366, 12 August 2010.

228. Harada, K.; Kato, M.; Saito, H.; Tsuchida, H.; Omura, T. Current Collector and Electrode Base Plate for Battery and Their Manufacturing Method. Jpn. Pat. Appl. 2006-310261, 9 November 2006.

229. Sugikawa, H. Production of Metallic Sheet and Metallic Sheet Produced by This Method. Jpn. Pat. Appl. H09-287006, 4 November 1997.

230. Sugikawa, H. Battery Can and Forming Material Thereof. Jpn. Pat. Appl. H05-021044, 29 January 1993.

231. Sugikawa, H. Method for Manufacturing Electrode Plate for Battery, Electrode Plate Manufactured by the Method, and Battery Provided with the Electrode Plate. Jpn. Pat. Appl. 2000-173603, 23 June 2000.

232. Kamiya, Y. Nickel-Metal Hydride Battery. Jpn. Pat. Appl. H08-227707, 3 September 1996.

233. Oshima, Y.; Kimura, K.; Nishimura, K.; Takasaki, T.; Ikeda, T. Mixture Ink for Forming Foil-Shape Collector Positive Electrode of Nickel-Metal Hydride Secondary Battery. Jpn. Pat. Appl. 2013-138001, 11 July 2013.

234. Tanaka, M.; Tokutake, N.; Kondo, Y.; Yamazaki, H.; Hirooka, M. Separator for Alkaline Battery and Alkaline Battery Using It. Jpn. Pat. Appl. H06-036753, 10 February 1994.

235. Hirooka, M.; Arimura, T.; Kawatsu, Y. Separator for Alkaline Battery. Jpn. Pat. Appl. H08-273650, 18 October 1996.

236. Sato, K.; Tanaka, M.; Hirooka, M. Separator for Alkaline Battery and Manufacture of the Separator. Jpn. Pat. Appl. 2000-106162, 11 April 2000.

237. Abe, M.; Tokuyama, E.; Okazaki, D.; Kokaji, T. Ball Mill Device, Method for Producing Hydrogen Storage Alloy Powder Using the Device and Hydrogen Storage Alloy Powder. Jpn. Pat. Appl. 2006-111909, 27 April 2006.

238. Osumi, Y.; Kato, A.; Suzuki, H.; Nakane, M.; Miyake, Y. Hydrogen absorption-desorption characteristics of mischmetal-nickel-aluminum alloys. J. Less Comm. Met. 1979, 66, 67-75. [CrossRef]

239. Osumi, Y.; Suzuki, H.; Kato, A.; Oguro, K.; Nakane, M. Development of misch metal-nickel and titanium-cobalt hydrides for hydrogen storage. J. Less Comm. Met. 1980, 74, 271-277. [CrossRef]

240. Osumi, Y.; Suzuki, H.; Kato, A.; Oruro, K. Hydrogen absorption-desorption characteristics of $\mathrm{MnNi}_{5-x} \mathrm{Al}(\mathrm{Mn})_{y-z} \mathrm{M}_{z}$ and $\mathrm{MmNi}_{5-x} \mathrm{AlMn}_{y} \mathrm{M}_{2}$ alloys $(\mathrm{Mm}=$ misch metal). J. Less Comm. Met. 1983, 89, 287-292. [CrossRef]

241. Osumi, Y. Suiso Kyuzou Goukin; Agune Co. Ltd.: Tokyo, Japan, 1993.

242. Kadir, K.; Sakai, T.; Uehara, I. Synthesis and structure determination of a new series of hydrogen storage alloys; $\mathrm{RMg}_{2} \mathrm{Ni}_{9}\left(\mathrm{R}=\mathrm{La}, \mathrm{Cel}, \mathrm{Pr}, \mathrm{Nd}, \mathrm{Sm}\right.$ and $\mathrm{Gd}$ ) built from $\mathrm{MgNi}_{2}$ Laves-type layers alternating with $\mathrm{AB}_{5}$ layers. J. Alloys Compd. 1997, 257, 115-121. [CrossRef]

243. Kuriyama, N.; Sakai, T.; Miyamura, H.; Uehara, H. Manufacture of Hydrogen Storage Electrode. Jpn. Pat. Appl. H06-283164, 7 October 1994.

244. Tsukahara, M.; Takahashi, K.; Mishima, T.; Isomura, A.; Sakai, T.; Miyamura, H.; Uehara, H. Hydrogen Occluding Alloy and Hydrogen Occluding Alloy Electrode. Jpn. Pat. Appl. H07-268513, 17 October 1995. 
245. Sakai, T.; Madono, J.; Miyamura, H.; Uehara, H. Hydrogen Storage Alloy and Electrode of It. Jpn. Pat. Appl. H07-278708, 24 October 1995.

246. Sakai, T.; Iwaki, T. Manufacture of Alkaline Secondary Battery and Catalytic Electrode Body. Jpn. Pat. Appl. H07-282860, 27 October 1995.

247. Kariimu, K.; Sakai, T.; Takeshita, H.; Uehara, H. New Hydrogen Storage Alloy and Hydrogen Electrode Using the Alloy. Jpn. Pat. Appl. H11-217643, 10 August 1999.

248. Sakai, T.; Takeshita, H.; Uehara, H.; Yamashita, I. Alkaline Secondary Battery Negative Electrode and Alkaline Secondary Battery. Jpn. Pat. Appl. H11-307088, 5 November 1999.

249. Osawa, M.; Tsunokake, S.; Katsura, S.; Iwaki, T.; Sakai, T. Hydrogen Storage Alloy and Nickel-Hydrogen Battery. Jpn. Pat. Appl. 2015-113522, 22 June 2015.

250. Mishima, R.; Sekine, T.; Sakai, T.; Ishikawa, H.; Miyamura, H.; Uehara, H. Hydrogen Storage Alloy and Its Production. Jpn. Pat. Appl. H06-145851, 27 May 1994.

251. Sakai, T.; Fukunaga, H.; Tanaka, T. Hydrogen Storage Alloy, and Electrode Using the Same. Jpn. Pat. Appl. 2003-059784, 6 March 2003.

252. Sakai, T.; Fukunaga, H.; Matsumoto, N.; Tanaka, T. Rectangular Nickel-Hydrogen Battery. Jpn. Pat. Appl. 2005-235421, 2 September 2005.

253. Kanemoto, M.; Kakeya, T.; Kurokuzuhara, M.; Watada, M.; Ozaki, T.; Sakai, T. Hydrogen Storage Alloy and Nickel-Hydrogen Storage Battery. Jpn. Pat. Appl. 2008-163421, 17 July 2008.

254. Ozaki, T.; Kanemoto, M.; Kakeya, T.; Kurokuzuhara, M.; Watada, M.; Sakai, T. Nickel-Hydrogen Storage Battery. Jpn. Pat. Appl. 2009-163986, 23 July 2009.

255. Kondo, T.; Yamamizu, T.; Sakai, T.; Kuriyama, N. Nickel Hydride Secondary Battery. Jpn. Pat. Appl. 2002-063889, 28 February 2002.

256. Kondo, T.; Yamamizu, T.; Sakai, T. Nickel Hydrogen Secondary Battery. Jpn. Pat. Appl. 2002-157988, 31 May 2002.

257. Iwaki, T.; Yao, M.; Sakai, T.; Okuno, K.; Kato, M.; Boku, T. Hydrogen Absorbing Alloy Negative Electrode for Alkaline Battery. Jpn. Pat. Appl. 2008-117579, 22 May 2008.

258. Mukai, T.; Takasaki, T.; Sakai, T.; Iwaki, T.; Tsutsumi, K.; Nishimura, K. Alloy Negative Electrode for Fiber Battery. Jpn. Pat. Appl. 2010-160912, 22 July 2010.

259. Takasaki, T.; Nishimura, K.; Fukunaga, H.; Tsutsumi, K.; Saito, M.; Mikai, T.; Sakai, T. Cobalt-Free Alkaline Secondary Battery. Jpn. Pat. Appl. 2012-204177, 22 October 2012.

260. Hashimoto, H.; Son, M.; Abe, T. Hydrogen Storage Material, and Production Method Therefor. Jpn. Pat. Appl. 2004-204309, 22 July 2004.

261. Sakai, T.; Iwaki, T. Electrode for Secondary Battery, and the Secondary Battery Using the Same. Jpn. Pat. Appl. 2003-326738, 18 September 2003.

262. Towata, S.; Ito, K.; Kadoura, H. Surface Treatment of Hydrogen Occlusion Alloy Material, Activation Treatment of Hydrogen Occlusion Alloy Electrode, Activating Solution, and Hydrogen Occlusion Alloy Electrode Having Excellent Initial Activity. Jpn. Pat. Appl. H08-291391, 5 November 1996.

263. Towata, S.; Ito, K.; Yamakawa, S.; Abe, K.; Oya, Y.; Morishita, S.; Kawase, Y. Surface Treatment Method of Hydrogen Storage Alloy by Steam and Alloy Obtained Thereby. Jpn. Pat. Appl. H09-180715, 11 July 1997.

264. Yoshida, T.; Miyano, K.; Itou, T.; Towata, S.; Ito, K. Hydrogen Storage Alloy Unit and Manufacture Thereof. Jpn. Pat. Appl. H10-012227, 16 January 1998.

265. Morishita, S.; Kondo, Y.; Towata, S.; Abe, K.; Muta, M.; Kinoshita, K. Nickel Positive Electrode Active Material for Alkali Storage Battery. Jpn. Pat. Appl. H10-074514, 17 March 1998.

266. Kondo, Y.; Morishita, S.; Oya, Y.; Towata, S.; Muta, M.; Kinoshita, K. Stabilizing Method for Hydrogen Storage Material. Jpn. Pat. Appl. H10-130860, 19 May 1998.

267. Muta, M.; Kinoshita, K.; Morishita, S.; Towata, S. Conductive Powder for Hydrogen Storage Alloy Negative Electrode. Jpn. Pat. Appl. H11-111299, 23 April 1999.

268. Morishita, S.; Towata, S.; Imaizumi, J.; Usui, T. Nickel Hydroxide for Positive Electrode Active Material of Alkaline Secondary Battery, Alkaline Secondary Battery Using Same, Its Characteristics Evaluation Method and Manufacturing Method. Jpn. Pat. Appl. 2002-208400, 26 July 2002.

269. Kobayashi, T.; Kondo, Y.; Matsuo, H.; Sasaki, I.; Ito, Y.; Nozaki, H.; Nonaka, T.; Senoo, Y.; Ukiyou, Y.; Ito, M. Alkaline Storage Battery. Jpn. Pat. Appl. 2005-347089, 15 December 2005. 
270. Yamawaki, K.; Kuwajima, S.; Suzuki, N.; Shirogami, T. Bipolar Metal-Hydrogen Secondary Battery. Jpn. Pat. Appl. H07-014618, 17 January 1995.

271. Tsutsumi, K. Laminate Battery and Laminate Battery System. Jpn. Pat. Appl. 2013-080698, 2 May 2013.

272. Ueda, K.; Tsukahara, M.; Kamiya, Y.; Kikuchi, S. Manufacturing Method for Mg-Cu Composite Material and Hydrogen Occluding Alloy. Jpn. Pat. Appl. 2005-178095, 7 July 2005.

273. Kamiya, Y.; Tsukahara, M. Hydrogen Storage Alloy and Hydrogen Storage Vessel. Jpn. Pat. Appl. 2006-028632, 2 February 2006.

274. Takahashi, K.; Tsukahara, M.; Mishima, T.; Isomura, A. Hydrogen Storage Alloy Electrode and Manufacture Thereof. Jpn. Pat. Appl. H08-236107, 13 September 1996.

275. Tsukahara, M.; Takahashi, K.; Mishima, T.; Isomura, A. Hydrogen Storage Alloy and Hydrogen Storage Alloy Electrode. Jpn. Pat. Appl. H08-269655, 15 October 1996.

276. Kamiya, Y.; Tsukahara, M.; Takahashi, K.; Isomura, A.; Sakai, T.; Takeshita, H. Hydrogen Storage Alloy, Hydrogen Storage Alloy Electrode and Production of Hydrogen Storage Alloy. Jpn. Pat. Appl. 2000-096179, 4 April 2000.

277. Tsukahara, M.; Kamiya, Y.; Takahashi, K.; Isomura, A.; Sakai, T.; Kuriyama, N.; Takeshita, H. Production of Hydrogen Storage Alloy, Alloy Thereof and Electrode Using the Alloy. Jpn. Pat. Appl. H11-106847, 20 April 1999.

278. Furukawa, K.; Sakamoto, K.; Mori, H.; Kishimoto, M.; Okabe, K. Sealed Nickel-Hydrogen Secondary Battery. Jpn. Pat. Appl. 2006-147327, 8 June 2006.

279. Furukawa, K.; Harada, Y. Battery. Jpn. Pat. Appl. 2007-234486, 13 September 2007.

280. Young, K.; Ouchi, T.; Fetcenko, M.A. Hydrogen Storage Alloys Having Improved Cycle Life and Low Temperature Operating Characteristics. U.S. Patent 7,344,677, 18 March 2008.

281. Sakamoto, K.; Bando, H.; Mori, H.; Okabe, K. Nickel Hydrogen Battery and Its Manufacturing Method. Jpn. Pat. Appl. 2007-012573, 18 January 2007.

282. Morimoto, K.; Saito, H.; Inaba, Y. Method of Manufacturing Nickel Metal Hydride Storage Battery. Jpn. Pat. Appl. 2010-010097, 14 January 2010.

283. Sakatani, T.; Sugui, H.; Ochi, M.; Kawase, R. Nickel Hydrogen Storage Battery and Battery System. Jpn. Pat. Appl. 2014-089896, 15 May 2014.

284. Sumiyama, S.; Shibuya, N.; Okabe, A. Nickel Hydrogen Storage Battery. Jpn. Pat. Appl. 2015-173058, 1 October 2015

(C) 2016 by the authors; licensee MDPI, Basel, Switzerland. This article is an open access article distributed under the terms and conditions of the Creative Commons Attribution (CC-BY) license (http://creativecommons.org/licenses/by/4.0/). 